\title{
Archaeological Investigations at 41AN115
}

\section{Ed Furman \\ Unknown}

Clyde Amick

Follow this and additional works at: https://scholarworks.sfasu.edu/ita

Part of the American Material Culture Commons, Archaeological Anthropology Commons, Environmental Studies Commons, Other American Studies Commons, Other Arts and Humanities Commons, Other History of Art, Architecture, and Archaeology Commons, and the United States History Commons

Tell us how this article helped you.

This Article is brought to you for free and open access by the Center for Regional Heritage Research at SFA ScholarWorks. It has been accepted for inclusion in Index of Texas Archaeology: Open Access Gray Literature from the Lone Star State by an authorized editor of SFA ScholarWorks. For more information, please contact cdsscholarworks@sfasu.edu. 


\section{Archaeological Investigations at 41AN115}

Creative Commons License

(c) () () (9)

This work is licensed under a Creative Commons Attribution-NonCommercial 4.0 International License 


\title{
ARCHAEOLOGICAL INVESTIGATIONS AT 41 AN115
}

\author{
Ed Fuman and Clyde Amick
}

\begin{abstract}
41AN115 is located in the northwestern part of Anderson County, Texas, on a western terrace of Town Creek approximately nine miles from the Trinity River. It is a multi-component prehistoric occupation, and the artifacts found here indicate it has been used from Late Paleoindian to Woodland period times. The late Paleoindian occupation is represented by Dalton and San Patrice dart points; the Archaic occupations are marked by Bell, Bulverde, and Yarbrough dart points; while the Woodland period occupation includes Gary points and sandy paste pottery. The site was used intermittently over thousands of years as a hunting camp and later as a seasonal campsite. The tool kit included flake knives, gravers, spokeshaves, punches, and scrapers, along with many ground stone tools. The lithic materials chosen for tool use are a combination of local and non-local material with cherts, fine-grained quartzite, ferruginous sandstone, and petrified wood. One Late Archaic occupational features has been found at the site.
\end{abstract}

\section{INTRODUCTION}

In November 1999, we received a call from Jason Wacha telling us he had Indian artifacts in his possession. These artifacts were taken from a field in Tucker, Texas, in Anderson County. Mr. Wacha hauls sand for an asphalt company. He showed us a single grooved axe and three chert blades that were approximately $10-15 \mathrm{~cm}$ long. He had also found six dart points, and he told us his boss had discovered another axe and several other artifacts. The following week, we received permission from the landowners, Mr. Bryant and Mr. Pearsoul, to go out to the site and confirm the existence of a prehistoric Indian occupation on the land. After several trips to the area, we reached the conclusion that there was an occupation of many thousands of years by hunter/gather peoples as evidenced by the dart points we found. After several weeks of surface collecting, we determined the areas of prehistoric occupation at the site (41AN115) to be at least $400 \mathrm{~m}$ long and approximately $60 \mathrm{~m}$ wide on an alluvial terrace (318 ft. amsl) on the western side of Town Creek. This area is within the Pineywoods, with a hardwood-pine forest, and an area of rolling hills and creeks that flow into the Trinity River.

\section{SITE DESCRIPTION}

Site 41 AN115 is located in Anderson County, nine miles west of Palestine in Anderson County. This camp sits on a north-northwestern-trending terrace with sandy loam sediments above Town Creek (Figure 1); the creek drains into the Trinity River. 


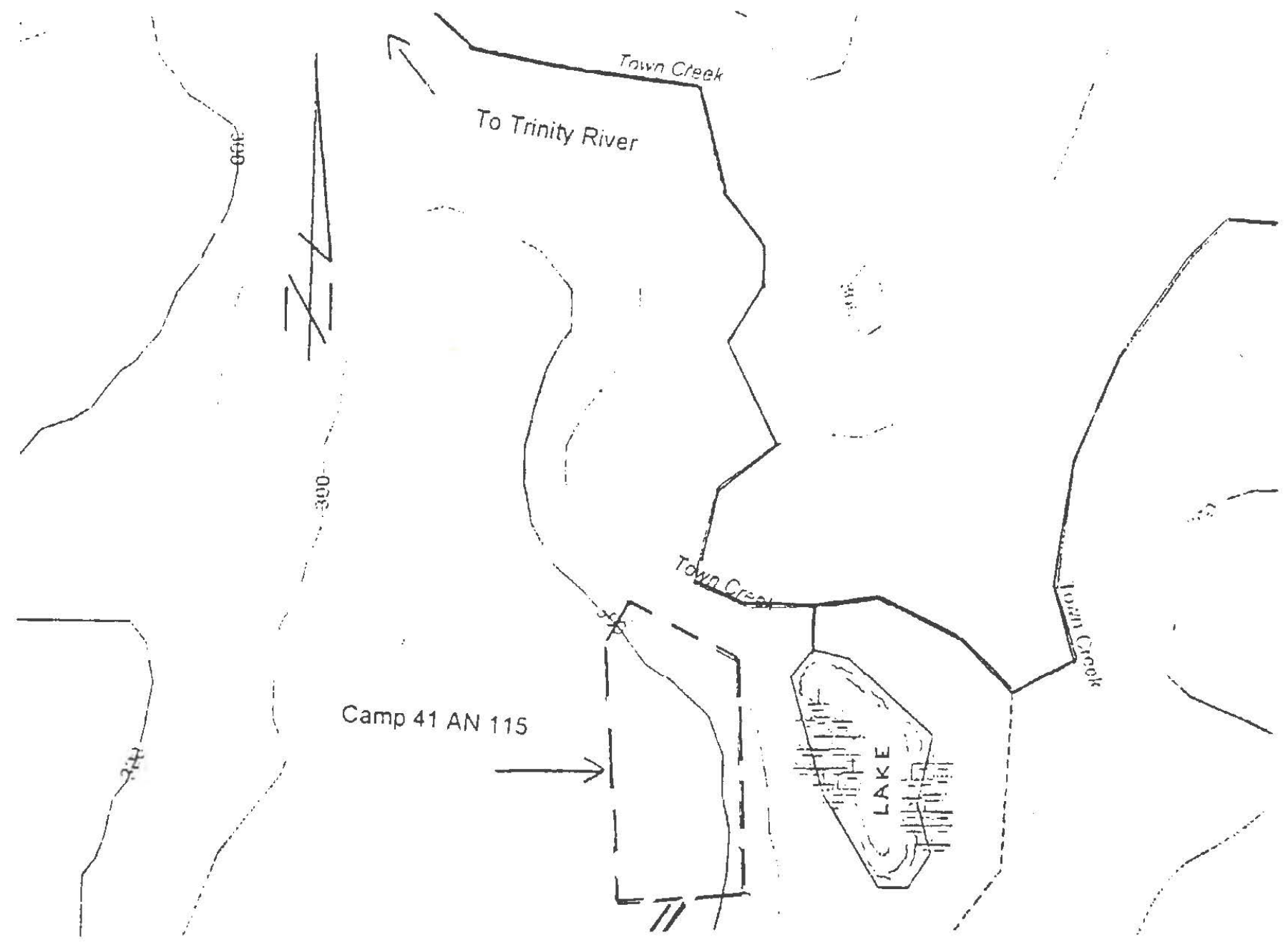

Figure 1. General location of 41AN115.

The site has been partially excavated by an asphalt company for the topsoil, destroying a large portion of the inhabited area. The site sits above the floodplain amid rolling hills, and creek drainages separated by dense foliage. The area around the site is a mixture of hardwoods and pine forest with scattered underbrush (especially along the creeks). The local vegetation consists of oak, hickory, walnut, pecan, elm, and pine trees, along with local plants such as wild onions, bull nettles, wild grapes, persimmon, and wild berries. Deer, fox, bear, wildcats, bison, ducks, armadillos, raccoons, and fish provided or still provide abundant game in the region. With the sandy topsoil, it would have been well-drained, and with numerous creeks and springs in the area for water supply; this site would have been ideal for camping by prehistoric peoples.

As for local materials for tool manufacturing, there are different types of river pebbles, including quartzite, cherts, and petrified wood found in abundant quantities. Ferruginous sandstone for tool manufacturing of both fine and coarse-grained texture are found in outcroppings along the creek drainage. These items were used as milling, grinding, and chopping tools. The prehistoric climate, especially during the later 
occupational periods, would have been mild, and along with an adequate rainfall and an abundance of plant, food and game, would have provided an ideal setting for the aboriginal inhabitants of this area.

\section{SOIL TYPES}

The entire site is on a series of old stream terraces formerly covered with hardwood forest. The top soil is a dark brown to gray fine sand to a depth of $1 \mathrm{ft}$. The next $2.7 \mathrm{ft}$ are yellowish-brown in color and slightly acidic, and the next layer, which may extend another $6.0 \mathrm{ft}$. in depth, is a yellowish-red sandy clay loam. With increasing soil depth, the soil acid content also increases. At the base is a compressed sandstone-like material.

The sandy soils have allowed for the vertical, but selective, migration of cultural materials from different periods of occupation which may provide an explanation for the varied character of the artifacts from the surface collection found at the base of the quarry after the removal of dirt down to an average depth of 6-8 ft. Repetitive occupations over a long period would provide such a varied and mixed collection.

After examining the cut banks of the excavated area, we noticed small pieces of chert debris on the natural top soil ( $0-1 \mathrm{ft}$. below surface). The lithic debris was fingernail to thumbnail-sized to $3.3 \mathrm{ft}$. below surface (bs), the approximate depth of an excavated fire pit (Fea. 1, see below).

From 3-5 ft. bs, small points, knives, small tools, and nutting stones were found. From depths below $5 \mathrm{ft}$. bs, larger projectile points, scrapers, hand axes, hammerstones, ground axes, anvil stones, and large grinding stones were found. Upon examination of the entire site (at this time more than four acres have been excavated for sand), small concentrations of fire-burned rock were noticed over all of it.

The high acid content of the soil explains the lack of preserved animal and plant remains, even though large amounts of burned rock was found. The fire pit (Fea. 1) was actually a "ball" of charcoal debris approximately $1.5 \mathrm{ft}$. in diameter. It was not a "flat" mass of charcoal as usually found in more recent Caddo sites. The area around the charcoal debris was gray in color, and radiated from the center of the feature several feet, gradually getting lighter in color. This indicates the mass was diluted in part by time but also with the help of the acid content of the soil and the high permeability of the sandy soil.

\section{DISTRIBUTION OF ARCHEOLOGICAL MATERIALS}

Stone tools and lithic debris at 41AN115 are scattered throughout the site with concentrations of material on the lower terrace at the southern end of the site, and also in the northern part along the creek drainage. Local lithic raw materials are found together 
with cherts from other areas, including chert from the Edwards Plateau, and smaller samples of chert from the Georgetown area of Central Texas (Larry Banks, personal communication). Most of the latter cherts were brought in to the site as dart points representing Paleoindian through Middle Archaic period occupations, with local lithic raw materials primarily present in Late Archaic and Woodland periods occupations.

We did find a stone tool cache of six stone tools buried together that were used in food preparation. In the North End of the site along the creek, in one area we found the eight arrow points and 11 pieces of pottery, and not far away, along the terrace edge, five gouges and one chisel were also recovered. Along the southern end of the terrace, chunks of petrified wood were most notably found, along with tools, both complete and broken (more numerous here than anywhere else) although petrified wood debitage and tools were scattered throughout the site.

\section{CHRONOLOGY}

This site was used from approximately 7,000 B.C. to A.D. 800 . This is based on the kind of dart points and arrow points that have been found here, as well as the sandy paste pottery. The oldest points we classified as Midland, Dalton, and San Patrice types. The lithic material from this early occupation was carried in from somewhere else, which is evidence for the highly mobile nature of the aboriginal people who used this area as a temporary campsite. Calf Creek, Wells, and Early Triangular point types represent the Early Archaic period occupation at 41AN115, while the Bulverde and Yarbrough points are from a Middle Archaic period occupation. The Williams, Darl, and Ensor points represent the Late Archaic period occupation. Gary and Kent points, with eight Steiner arrow points and seven sherds of sandy paste pottery, evidence the use of the site in the Woodland period.

This periodic occupation over several thousand years was primarily by aboriginal peoples who camped here only briefly to refurbish projectile points or to carry off broken ones and replace them with new points. Later, there is evidence that seasonal occupations were taking place at 41AN115. These occupations are marked by the stone tools that they used for food preparation, then left, while the people moved on to the next camp. There are indications in the archaeological findings that as more organized societies began to form in the Woodland period, that people were staying on this terrace for longer periods of time than they had during much of the Archaic. With the discovery of ground stone tools for food preparation, pottery sherds, and the arrow points, this might indicate that they were just beginning to become more sedentary, began to cultivate plants, and perhaps to have had permanent housing. Over thousands of years, therefore, the aboriginal people evolved into farmers and had extended families and societal boundaries.

There was one feature found at the site, a fire pit, at the base of a sand embankment, $3.5 \mathrm{ft}$ bs (see below). A calibrated radiocarbon date ( 2 sigma) on charcoal in the feature ranges from 2060-2450 B.C. (Perttula 2002). 


\section{DESCRIPTION OF CHIPPED STONE ARTIFACTS}

Because of space limitations, not all of the chipped stone artifacts from 4IAN115 are described below or are illustrated in this article. Consequently, certain artifacts are representative of those that could be identified, and they are described in more detail below. The types of chipped artifacts include the following categories:

- Dart Points

- Arrow Points

- Scrapers

- Knives

- Awls

- Gravers

\section{Dart Points}

The dart points (Table 1) are classified by the descriptions provided in the Field Guide to Sione Artifacts of Texas by E. Sue Turner and Thomas R. Hester (1993). They are also separated by age in the descriptions, as follows:: Paleoindian, Early Archaic, Middle Archaic, Late Archaic, and Woodland periods.

Table 1. Summary of projectile points found at 41AN115

Point Type No. of Specimens

\begin{tabular}{ll}
\hline Angostura & 2 \\
Plainview & 2 \\
Hell Gap & 1 \\
Golondrina & 1 \\
San Partice & \\
Early Stemmed & 2 \\
Wells & 1 \\
Early Triangular & 6 \\
Bell & 4 \\
Dalton & 3 \\
Bulverde & 3 \\
Val Verde & 5 \\
Dawson & 1 \\
Yarbrough & 4 \\
Morrill & 2 \\
Williams & 1 \\
Hoxie & 1 \\
Carrollton & 2 \\
\end{tabular}


Table 1. Summary of projectile points found at 41 AN115, cont

\begin{tabular}{ll} 
Point Type & No. of Specimens \\
\hline Trinity & 1 \\
Morhiss & 2 \\
Marcos & 2 \\
Darl & 2 \\
Ensor & 6 \\
Elam & 5 \\
Gary & 23 \\
Kent & 6 \\
Steiner (arrow points) & 8 \\
Fragments & 74
\end{tabular}

Total

172

\section{Paleoindian Points}

Angostura point (Figure 2a): leaf-shaped point with basal grinding; parallel flaking; tan chert, non-local material; lightly serrated along the sides; $95 \mathrm{~mm}$ long, $30 \mathrm{~mm}$ wide, and $10 \mathrm{~mm}$ thick.

Angostura point (Figure 2b): leaf-shaped, with basal grinding; serrated blade, base is broken and has been re-flaked; lustrous creamy white chert, may have been heat-treated; non-local material; $73 \mathrm{~mm}$ long, $28 \mathrm{~mm}$ wide, and $10 \mathrm{~mm}$ thick.

Dalton point (Figure 2c): lanceolate point with basal grinding; concave base with just the tip of one of the barbs broken off; gray chert, non-local material; slightly beveled sides. Chipping not of the best workmanship; $43 \mathrm{~mm}$ long, $20 \mathrm{~mm}$ wide, and $5 \mathrm{~mm}$ thick.

Dalton point (Figure 2d): lanceolate point with basal grinding; beveled along the sides,

thin, and very well-chipped; lightly serrated; parallel flaking; light to dark tan chert, nonlocal material; deep concave base; $60 \mathrm{~mm}$ long, $25 \mathrm{~mm}$ wide, and $6 \mathrm{~mm}$ thick.

Plainview (Figure 2e): lanceolate-shaped with the tip broken off and re-flaked into a unifacial tool; basal grinding; slightly concave base with thinning exhibited by small vertical flakes; light red chert, non-local material; $43 \mathrm{~mm}$ long, $30 \mathrm{~mm}$ wide, and $7 \mathrm{~mm}$ thick. 


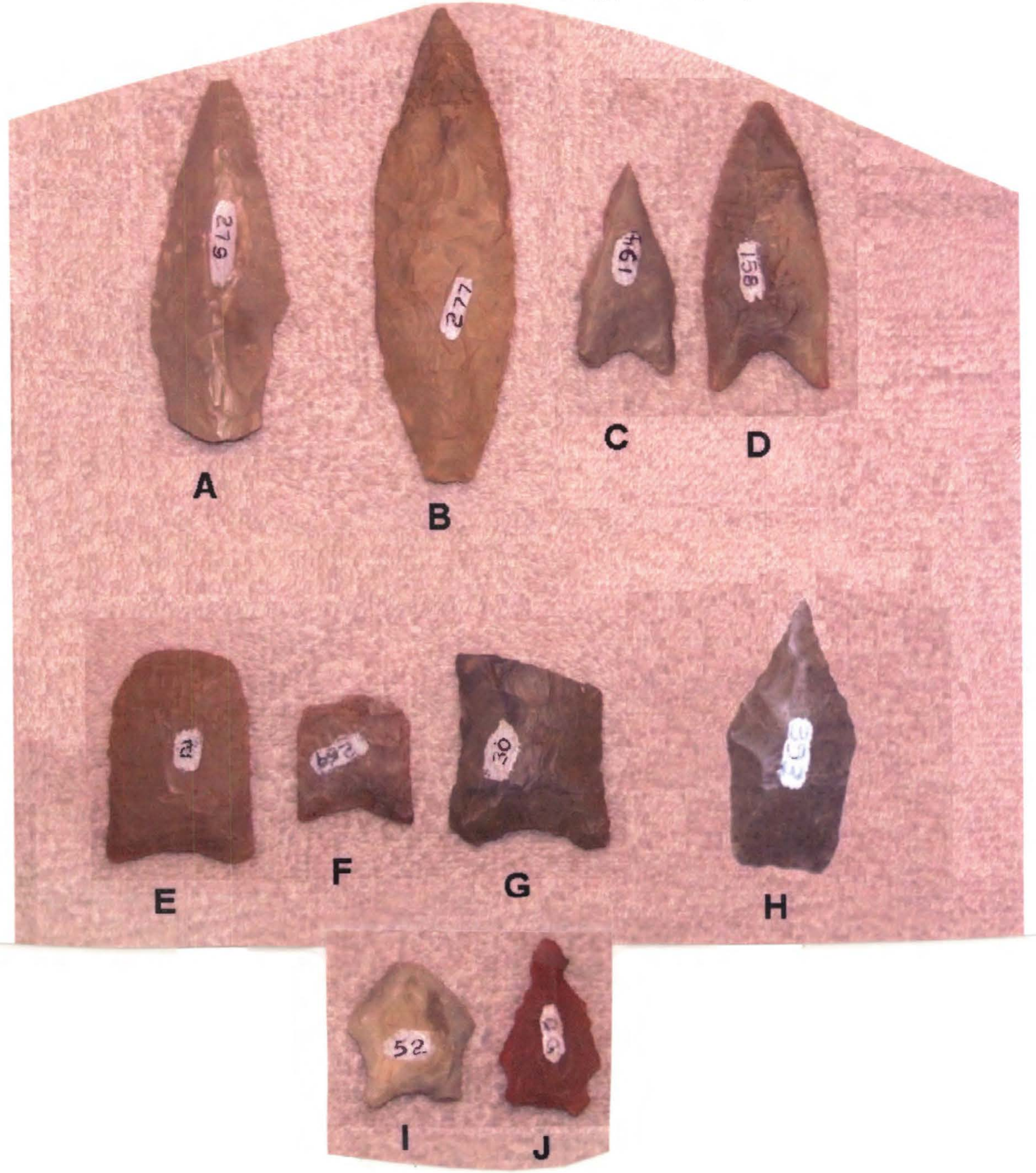

Figure 2. Paleoindian dart points from 41AN115. 
Midland (Figure 2f): lanceolate-shaped point, very thin; exhibits basal grinding with a slightly concave base; base well thinned with vertical flaking; tan chert, non-local material; tip was broken off, and re-flaked to produce a unifacial tool; $25 \mathrm{~mm}$ long, 22 $\mathrm{mm}$ wide, and $4 \mathrm{~mm}$ thick.

Firstview, point (Figure 2g): a broad, thick lanceolate, with basal grinding, and a concave base; wedge shaped across the middle, and with the distal tip broken off; non-local bluish-gray chert; $40 \mathrm{~mm}$ long, $38 \mathrm{~mm}$ wide, and $50 \mathrm{~mm}$ thick.

Un-typed, lanceolate shape (Figure 2h): square base, with basal grinding; brown chert, non-local material; . Tip broken off distal end, and a new tip was flaked to shape it into a drill or awl; $42 \mathrm{~mm}$ long, $22 \mathrm{~mm}$ wide, and $7 \mathrm{~mm}$ thick.

San Patrice point: concave base, with basal grinding; one tip of one of the barbs is broken off, weak shoulders (Figure 2i); light gray chert material, non-local; both sides were beveled; This point may have been resharpened until it was of no farther use; 30 $\mathrm{mm}$ long, $27 \mathrm{~mm}$ wide, and $5 \mathrm{~mm}$ thick.

San Patrice point: crudely made, weak shoulders, with slightly concave base (Figure $2 \mathrm{j}$ ); rough flaking along the sides; the point made from a red chert, non-local; $33 \mathrm{~mm}$ long, 22 $\mathrm{mm}$ wide, and $5 \mathrm{~mm}$ thick.

\section{Early Archaic Points}

Early Triangular (Figure 3a): well-thinned base, sides lightly serrated; non-local bluishgray chert with white flecks; $40 \mathrm{~mm}$ long, $30 \mathrm{~mm}$ wide, and $5 \mathrm{~mm}$ thick.

Early Triangular: well-thinned base, and finely serrated sides (Figure 3b); non-local chert, gray in color; $45 \mathrm{~mm}$ long, $28 \mathrm{~mm}$ wide, and $5 \mathrm{~mm}$ thick.

Early Triangular: well-thinned base and serrated sides (Figure 3c); non-local material, a creamy gray chert with dark gray impurities in the middle; $55 \mathrm{~mm}$ long $35 \mathrm{~mm}$ wide, and $6 \mathrm{~mm}$ thick.

Early Triangular: base well-thinned, vertical flaking, and finely serrated (Figure 3d); creamy-gray chert of non-local material; $40 \mathrm{~mm}$ long, $26 \mathrm{~mm}$ wide, and $4 \mathrm{~mm}$ thick.

Calf Creek: large wide triangular point, with both barbs broken off (Figure 3e); one broken at the blade, and the tip of the other broken off; the tip of the point is also broken off; it has a wide parallel stem, with a straight base; grayish-blue lustrous chert; may have been heat treated; non-local lithic material; $68 \mathrm{~mm}$ long, $39 \mathrm{~mm}$ wide and $6 \mathrm{~mm}$ thick.

Calf Creek: one barb completely chipped off, and a well-made barb on the other side; straight parallel stem, with square base, lightly serrated (Figure 3f); tan chert, of nonlocal material; $53 \mathrm{~mm}$ long, $40 \mathrm{~mm}$ wide, and $5 \mathrm{~mm}$ thick. 


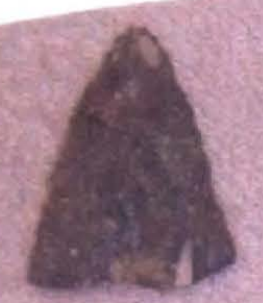

A

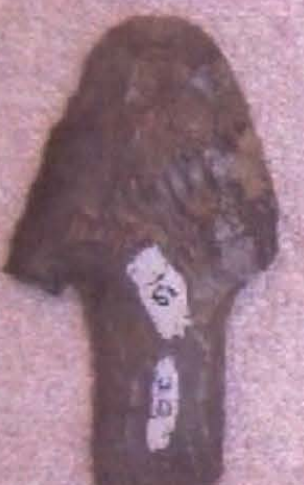

E

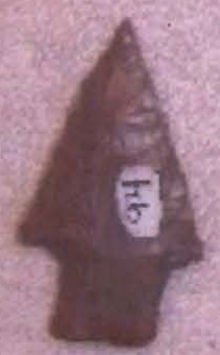

I

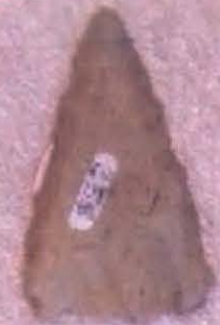

B

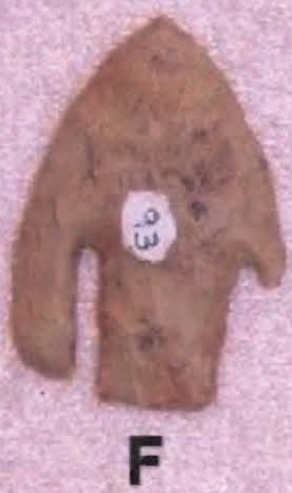

F

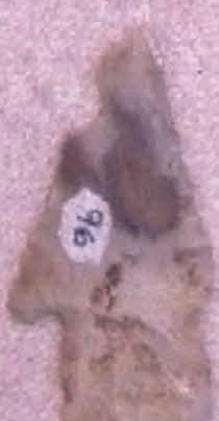

J

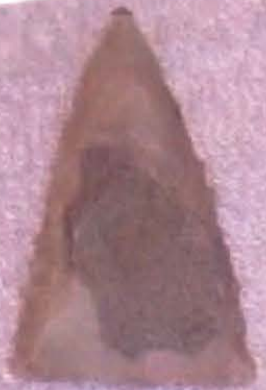

C

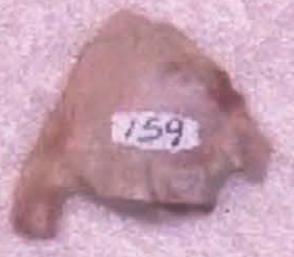

G

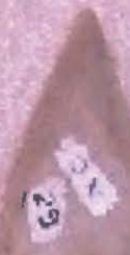

D
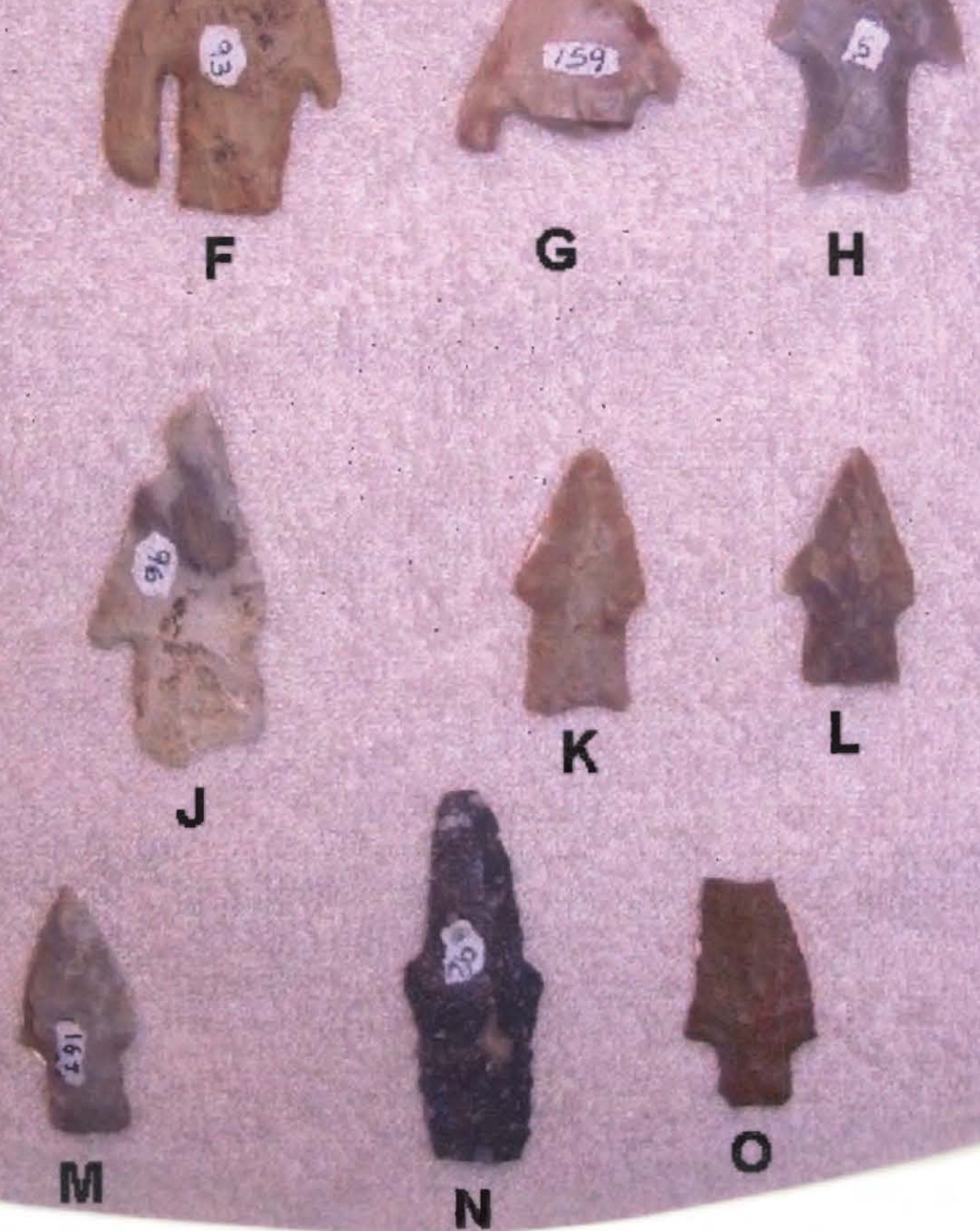

Figure 3. Early Archaic dart points from 41AN115. 
Calf Creek: both proximal and distal ends broken off, one barb is completely broken, and the tip of the other barb is missing (see Figure $3 \mathrm{~g}$ ); lightly serrated sides; white chert with light brown inclusions; probably heat treated; a non-local material; $31 \mathrm{~mm}$ long, $38 \mathrm{~mm}$ wide, and $6 \mathrm{~mm}$ thick.

Calf Creek: may have been resharpened to a point that it was not a usable tool; there is a notch in the middle of one side, with one barb broken off at the shoulder, and the other side only has a small barb (see Figure $3 \mathrm{~h}$ ); parallel stem, with square base; gray chert or novaculite; non-local material; $41 \mathrm{~mm}$ long, $32 \mathrm{~mm}$ wide, and $6 \mathrm{~mm}$ thick.

Bulverde: triangular-shaped pint with straight parallel stem, and square base; wedgeshaped body, with light serrations along the sides (see Figure 3i); light brown chert; lustrous, which may indicate heat treatment of this non-local material; base thinned with vertical flaking; $46 \mathrm{~mm}$ long, $27 \mathrm{~mm}$ wide, and $7 \mathrm{~mm}$ thick.

Bulverde: large triangular point, with straight sides that have fine serrations along the lateral edges; stem has straight parallel sides, with one side of the base broken off (sce Figure $3 \mathrm{j}$ ); one of the barbs has been chipped even with the blade, and the tip is broken off the other side; along one of the sides, there is a flake that has been deliberately removed; white raw material, with gray at the distal end; a non-local material; $60 \mathrm{~mm}$ long, $30 \mathrm{~mm}$ wide, and $6 \mathrm{~mm}$ thick.

Bulverde: triangular point with straight sides that are lightly serrated; stem has straight parallel sides, with a slightly concave base (see Figure $3 \mathrm{k}$ ); wedge-shaped in appearance, made from a light reddish-gray chert; $45 \mathrm{~mm}$ long, $23 \mathrm{~mm}$ wide, and $6 \mathrm{~mm}$ thick.

Bulverde: triangular point with straight sides, with one barb missing; wedge-shaped blade; gray chert with light gray inclusions;.parallel stem, with a straight and thinned base (see Figure 31); this point is made from a non-local material; $38 \mathrm{~mm}$ long, $27 \mathrm{~mm}$ wide, and $6 \mathrm{~mm}$ thick.

Bulverde: triangular point, with straight sides and weak shoulders; stem has parallel sides, and a square base (see Figure $3 \mathrm{~m}$ ); wedge-shaped body, with well-thinned base; light gray non-local lithic raw material; $40 \mathrm{~mm}$ long, $21 \mathrm{~mm}$ wide, and $10 \mathrm{~mm}$ thick.

Wells: long narrow shape, with the stem approximately one third of the length (see Figure $3 \mathrm{n}$ ); the sides are serrated, and the stem is tapered to a square base; black chert with white specks; a non-local material; the distal end is broken off; $60 \mathrm{~mm}$ long, $25 \mathrm{~mm}$ wide, and $7 \mathrm{~mm}$ thick.

Yarbrough: straight sides, with small shoulders (see Figure 3o); slightly expanded stem with a slightly concaved base; distal end is broken; made from a local light brown chert; $40 \mathrm{~mm}$ long, $25 \mathrm{~mm}$ wide, and $6 \mathrm{~mm}$ thick. 


\section{Middle Archaic Points}

Williams (Figure 4a): broad triangular shape, corner notched, with an expanding stem; nicely chipped with blades lightly serrated; it is made of a tan chert, probably from Central Texas; non-local; some cortex on the base of the stem; $51 \mathrm{~mm}$ long, $32 \mathrm{~mm}$ wide, and $7 \mathrm{~mm}$ wide.

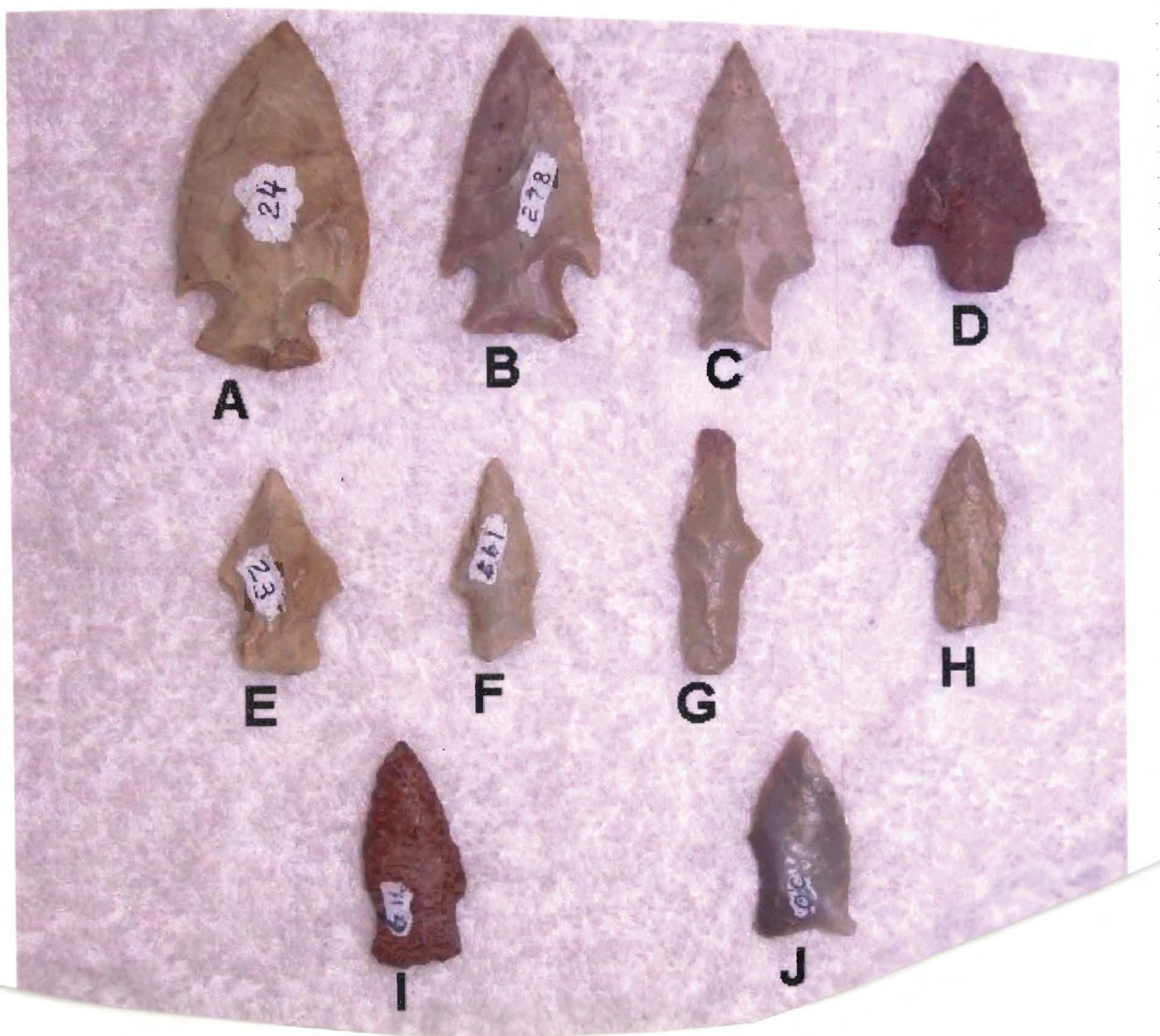

Figure 4. Middle Archaic dart points from 41AN115. 
Marshall: triangular point with barbs made by corner notching; expanding stem (Figure 4b); well-chipped; the blades are lightly serrated, and the base exhibits evidence of basal grinding; it is a light and dark gray non-local chert, possibly heat-treated; $50 \mathrm{~mm}$ long, 26 mm wide and $5 \mathrm{~mm}$ thick.

Langtry: triangular body, with straight sides, with side notching, and a slight expanding stem (Figure 4c)l the base of the stem is slight concave, and has basal grinding; the material is light gray chert from the Edwards Plateau area; $50 \mathrm{~mm}$ long, $24 \mathrm{~mm}$ wide, and $8 \mathrm{~mm}$ thick.

Carrollton: a short triangular point, straight sides, and squared off at the shoulders (Figure 4d); the stem is short and contracting, with basal grinding present. This is made from a local red chert; $35 \mathrm{~mm}$ long, $26 \mathrm{~mm}$ wide and $5 \mathrm{~mm}$ thick.

Elam: the stem makes up approximately $50 \%$ of the length of the whole point; the stem has parallel sides produced by side notching (Figure 4e); the material is a local light gray chert found along creek beds in the area; $30 \mathrm{~mm}$ long $21 \mathrm{~mm}$ wide, and $10 \mathrm{~mm}$ thick.

Dawson: narrow triangular point with a stem that comprises approximately $50 \%$ of the length of the point (Figure 4f); this point has part of the stem broken off, and small shoulders produced by side notching; the material is a gray chert, most likely from the Edward Plateau area; $40 \mathrm{~mm}$ long $15 \mathrm{~mm}$ wide and $6 \mathrm{~mm}$ thick

Dawson: a narrow point with the distal tip broken off; weak shoulders, produced by side notching with one shoulder removed by resharpening; the stem is approximately $50 \%$ of the length of the point and has parallel sides with a rounded base (Figure $4 \mathrm{~g}$ ); this point has been rc-chipped into a punch or awl; this point is made of a non-local material, a gray chert probably from the Edwards Plateau area; $31 \mathrm{~mm}$ long $15 \mathrm{~mm}$ wide and $5 \mathrm{~mm}$ thick.

Dawson: a narrow point with the stem making up approximately $50 \%$ of the length; the shoulders are weak, with one having been resharpened even with the blade; the bottom of the stem has been just slightly broken (Figure $4 \mathrm{~h}$ ); the point is a non-local gray chert probably brought in from the Edwards Plateau area; there is basal grinding on the stem, and the edges of the blades are straight; $32 \mathrm{~mm}$ long $15 \mathrm{~mm}$ wide and $6 \mathrm{~mm}$ thick

Trinity: side notched, with a slightly expanding stem (Figure 4i); the small blade has straight sides, with very weak shoulders; non-local material, may be a red petrified palm wood; $37 \mathrm{~mm}$ long, $17 \mathrm{~mm}$ wide, and $6 \mathrm{~mm}$ thick.

Trinity: weak shoulders, with a slightly expanded stem (Figure 4j); the base is concave, with basal grinding; made from a lustrous, gray chert of non-local material; $32 \mathrm{~mm}$ long, $17 \mathrm{~mm}$ wide, and $7 \mathrm{~mm}$ thick.

\section{Late Archaic Points}

Darl: (Figure 5a): a long slender point, with its base comprising approximately $50 \%$ of its 
length; the base has parallel sides with basal grinding along its sides, and it is square along the bottom; the sides of the blade are straight and lightly serrated; this point is made from non-local material, possibly from Georgetown, Texas, and is blue in color; 80 $\mathrm{mm}$ long, $20 \mathrm{~mm}$ wide and $7 \mathrm{~mm}$ thick.

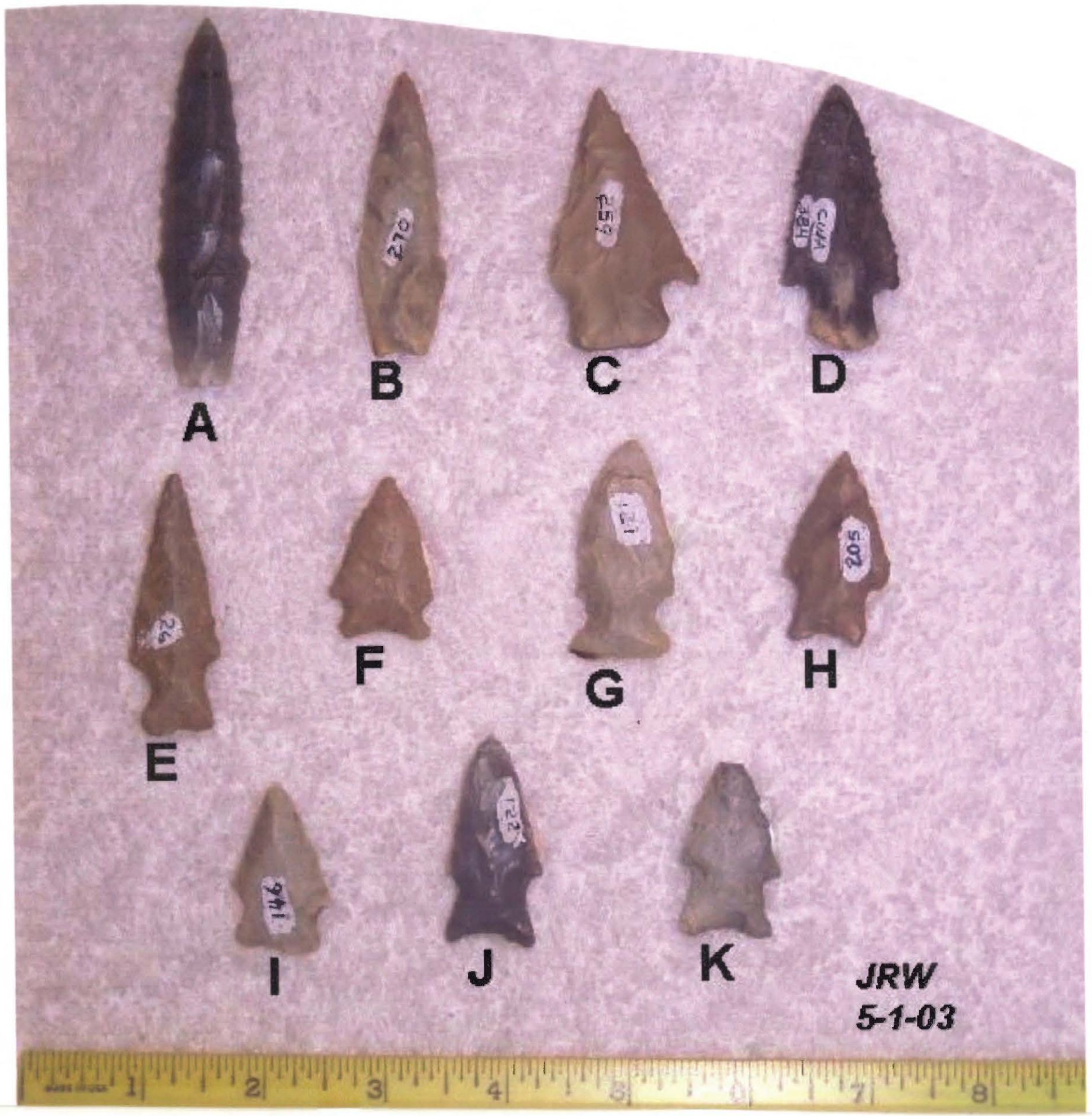

Figure 5. Late Archaic dart points from 41AN115. 
Darn: a slender point with a blade having straight edges, and the sides of the base are slightly contracting (Figure 5b); the sides of the blades have been resharpened so that they are smaller than the sides of the base; the opposite sides of the blade are beveled; basal grinding along the stem, and the bottom is concave; the chert is gray in color, probably from the Edwards Plateau area; $60 \mathrm{~mm}$ long, $20 \mathrm{~mm}$ wide and $5 \mathrm{~mm}$ thick.

Lange: a triangular point, with straight sides along the blade and stem, with a flat base (Figure 5c); one shoulder has been resharpened, and the other is well-barbed; it is made from a gray chert, non-local, and may have been heat treated; $52 \mathrm{~mm}$ long, $31 \mathrm{~mm}$ wide, and $5 \mathrm{~mm}$ thick.

Godley: a triangular point, with weak shoulders, but no barbs, and a slightly expanding convex base (Figure 5d); the base has some cortex on the bottom, and the sides of the blades are finely serrated; the lithic raw material is a smoky dark gray, possibly a local material found along the creek beds, where it occurs as rounded pieces of chert; $55 \mathrm{~mm}$ long, $25 \mathrm{~mm}$ wide, and $10 \mathrm{~mm}$ thick.

Godley: a narrow point with weak shoulders, and an expanding stem (Figure 5e); it has a straight base, with basal grinding; the raw material is a local gray chert; $53 \mathrm{~mm}$ long, 20 $\mathrm{mm}$ wide, and $5 \mathrm{~mm}$ thick.

Fairland: a broad triangular point, with small shoulders and a wide flaring concave base, as wide as the shoulders (Figure 5f); the base is wcll thinned, and the edges of the blade are straight; the raw material is a light brown chert; non-local; $35 \mathrm{~mm}$ long, $21 \mathrm{~mm}$ wide, and $4 \mathrm{~mm}$ thick.

Ensor: it has a broad base with shallow side notches that are the same width as the shoulders (Figure 5g); the point is thick, and the workmanship is not of good quality; one side of the blade is curved to the tip, and the other is straight; creamy gray chert, most likely from the Edwards Plateau area; $45 \mathrm{~mm}$ long, $21 \mathrm{~mm}$ wide, and $9 \mathrm{~mm}$ thick.

Edgewood: a small triangular point with an expanding stem and a concave base (Figure $5 \mathrm{~h}$ ); a smoky gray chert of non-local origin; side notching with small shoulders; $40 \mathrm{~mm}$ long, $20 \mathrm{~mm}$ wide and $5 \mathrm{~mm}$ thick.

Fairland: a small triangular point with side-notching and an expanding stem (Figure 5i); the sides are straight on the blades, and the base is well-thinned; gray chert of non-local material; $35 \mathrm{~mm}$ long, $20 \mathrm{~mm}$ wide, and $5 \mathrm{~mm}$ thick.

Fairland: a triangular point with small shoulders, and a base that expands out as wide as the shoulders (Figure 5j); the point is well-chipped, and the chert raw material used to make the point is probably heat treated; the base is concave, and has basal grinding; dark gray chert, of non-local origin; $45 \mathrm{~mm}$ long, $26 \mathrm{~mm}$ wide, and $7 \mathrm{~mm}$ thick.

Fairland: a broad triangular point, with an expanding base as wide as the shoulders; the shoulder are weak and are produced by side-notching; the base is concave (Figure 5k); 
the very tip of the point is broken off but the tool is well-chipped; the lithic raw material is non-local; $36 \mathrm{~mm}$ long, $23 \mathrm{~mm}$ wide, and $4 \mathrm{~mm}$ thick.

\section{Woodland Period Points}

Gary (Figure 6a): a triangular-shaped point, with pronounced barbs and a contracting stem; both sides of the blade are chipped toward the point; the point is thicker and the workmanship in the chipping is not of the best quality; red chert that is found locally in the area; $21 \mathrm{~mm}$ long, $25 \mathrm{~mm}$ wide, and $7 \mathrm{~mm}$ thick.

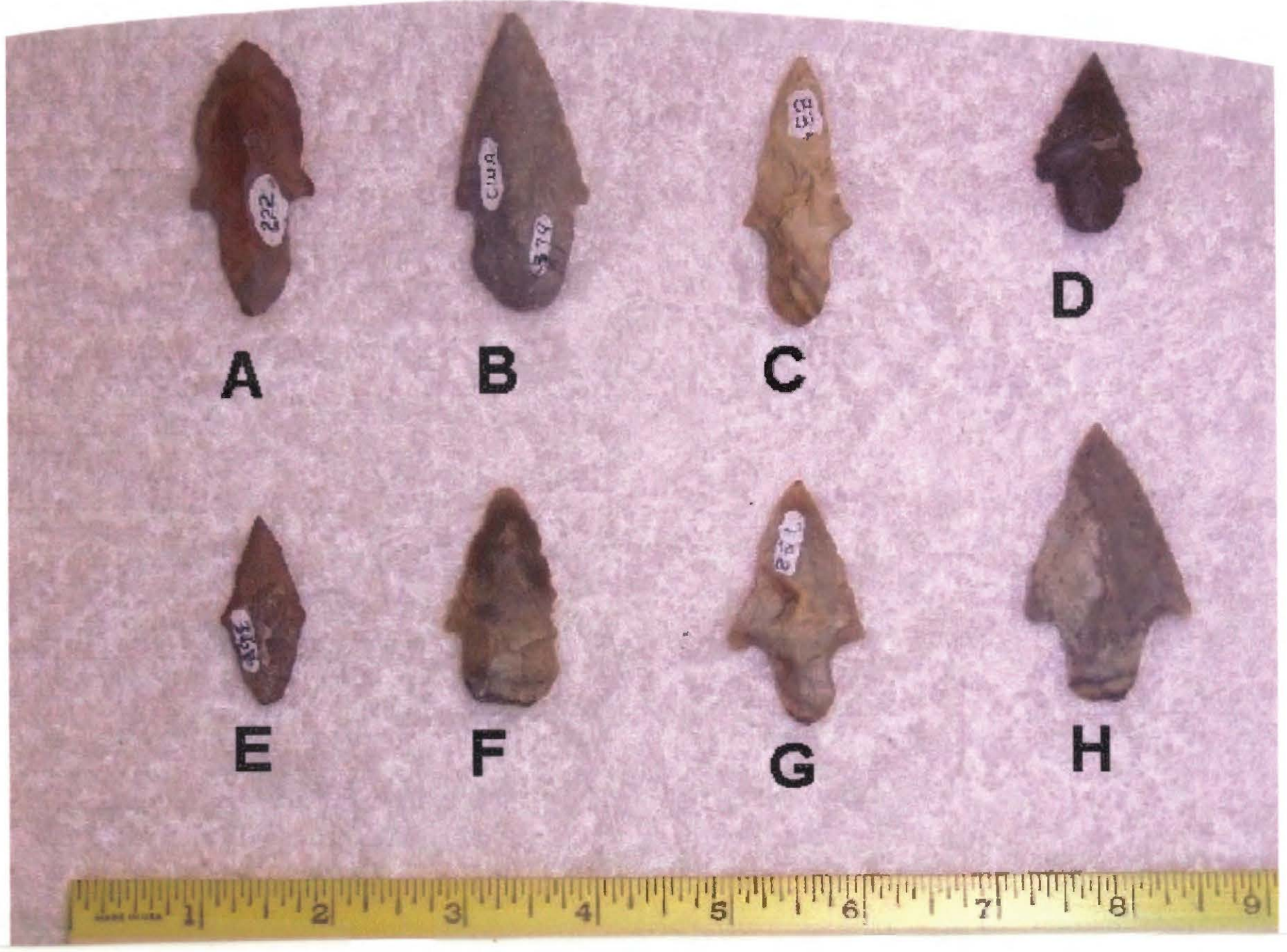

Figure 6. Woodland period dart points from 41AN115. 
Gary: a triangular point, with straight edges on the blade, and small shoulders; contracting stem (Figure 6b); the edges of the blade are slightly serrated, and there is some basal grinding; gray flint, not local, probably from the Edwards Plateau area; 60 $\mathrm{mm}$ long, $28 \mathrm{~mm}$ wide, and $8 \mathrm{~mm}$ thick.

Gary Point: a slender point, resharpened, with small barbs, and a contracting stem (Figure $6 c)$; light brown local chert; basal grinding along the stem; $21 \mathrm{~mm}$ long, $23 \mathrm{~mm}$ wide and $6 \mathrm{~mm}$ thick

Gary: a small triangular shouldered point; contracting stem and a rounded base (Figure $6 \mathrm{~d})$; dark brown chert; light serrations along the sides of the blades; $53 \mathrm{~mm}$ long, $21 \mathrm{~mm}$ wide and $7 \mathrm{~mm}$ thick.

Gary (Figure 6e): another small example of a Gary point (see Figure 6d), crudely made, whose base is as long as the blade; this point may have been resharpened due to use; a small triangular point, with small shoulder, and a contracting base; local red chert. $35 \mathrm{~mm}$ long, $17 \mathrm{~mm}$ wide, and $5 \mathrm{~mm}$ thick.

Kent: a crudely made triangular point with only one shoulder (Figure 6f), the other having been chipped off; a parallel stem with some cortex along the bottom of the base; the base is square along the bottom; gray raw material, with smoky dark splotches on the blade; $41 \mathrm{~mm}$ long, $25 \mathrm{~mm}$ wide, and $7 \mathrm{~mm}$ thick.

Kent: a crudely made triangular point, with a contracting and rounded base (Figure $6 \mathrm{~g}$ ); on one side of the blade, there is an area excessively thinned, due to a hinge fracture; small shoulders, with one barb more pronounced than the other; $45 \mathrm{~mm}$ long, $25 \mathrm{~mm}$ wide, and $5 \mathrm{~mm}$ thick.

Kent: a broad triangular point with square shoulders and one pronounced barb (Figure 6h); the other was removed during resharpening; the stem is contracting, formed by side notching, with a rounded base with cortex along the bottom; the material is a non-local gray chert, probably from the Edwards Plateau area; $53 \mathrm{~mm}$ long, $34 \mathrm{~mm}$ wide, and $8 \mathrm{~mm}$ thick.

\section{Arrow Points}

Steiner (Figure 7a): a triangular point with straight serrated edges along the blade; a slightly expanding stem; one barb is completely broken off and the other has the end of the barb broken off; local reddish-brown chert; $26 \mathrm{~mm}$ long, $13 \mathrm{~mm}$ wide, and $3 \mathrm{~mm}$ thick.

Steiner: a small triangular point, with serrated edges along the edges of the blade, with lateral spurs along one side (Figure $7 \mathrm{~b}$ ); the bottom of the stem is concave and the sides of the stem are parallel, up to the small shoulders that protrude on each side; local tan chert; $25 \mathrm{~mm}$ long and $14 \mathrm{~mm}$ wide and $3 \mathrm{~mm}$ thick. 


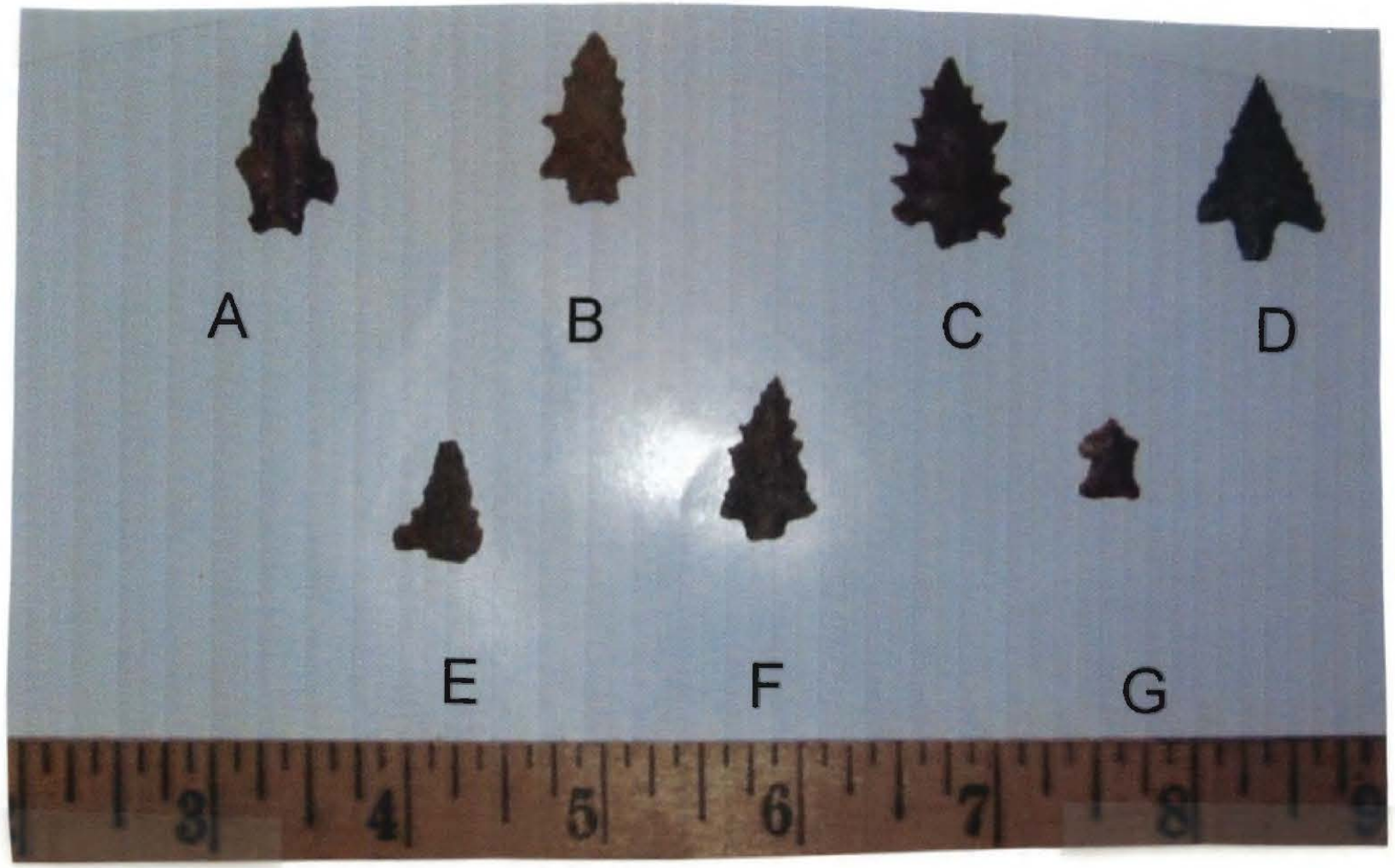

Figure 7. Arrow points from 41AN115.

Steiner: a triangular point with lateral spurs on each side of the blade, with a small straight and stemmed base (Figure 7c) that is concave at the bottom; local reddish-brown chert; $25 \mathrm{~mm}$ long, $17 \mathrm{~mm}$ wide, and $3 \mathrm{~mm}$ thick.

Perdiz: a small triangular point with well-barbed and pointed shoulders, and a small contracted stem (Figure 7d); the lateral edges of the blade are serrated on each side, and the blade comes to a fine point on the distal end; non-local black chert; $25 \mathrm{~mm}$ long, and $17 \mathrm{~mm}$ wide, and $3 \mathrm{~mm}$ thick.

Steiner: a small triangular point, with the tip and one shoulder broken; the stem was snapped off the point (Figure 7e); the lateral edges are serrated, with one bulbous shoulder; $15 \mathrm{~mm}$ long, $12 \mathrm{~mm}$ wide, and $3 \mathrm{~mm}$ thick.

Steiner: a small triangular point, with small spurs along each of the lateral edges (Figure $7 \mathrm{f}$ ); the stem is small, with a slightly concave abase; local dark gray chert; $22 \mathrm{~mm}$ long, $13 \mathrm{~mm}$ wide, and $4 \mathrm{~mm}$ thick.

We cannot type one of the arrow points from 41AN115 because it is very small (Figure 7g), and probably not made to be used as a stone arrow. This small point was probably an ornament, made to be worn on a person. It is triangular-shaped, with an expanding base. It is made from a local red chert. 


\section{Summary of Projectile Points}

Of the 90 dart points, eight arrow points, and 74 fragments (see Table 1), 37 are on local lithic raw material, and 47 points are made of cherts brought in from other sources outside the local area. Aftcr discussions with other archaeologists, the non-local cherts came from the Fdwards Plateau, the Georgetown area of Central Texas, and from the Ouachita Mountains in southwestern Arkansas. We found six preform blanks of a gray chert at 4l AN115, so we know that aboriginal peoples carried lithic raw materials with them when they came through the area. The rest of the point collection is comprised of petrified wood, quartzite, and local cherts indigenous to this area. Also, we can see as time went on, there was a gradual mix of local materials that began to be used, until by the Woodland period, the majority of points were made out of materials available along the local creek beds and outcroppings.

Because of the lithic material we collected (especially lithic debris), we can see that not only were the peoples that occupied 41AN1 15 in prehistoric times remanufacturing and re-sharpening existing points, they were making new ones as they needed them. We found points in different stages of manufacture, and points re-flaked into other tools from broken ones. We found different types of flakes, from hard hammer flakes and spalls, with cortex on them, to thin ribbon flakes made by soft hammer techniques, and the small pressure flakes.

As far as the distribution of projectile points is concerned, only at the north end of the site do the same point types seem to be spatially concentrated. In that area, we found all seven arrow points, seven sherds of sandy paste pottery, and some Woodland period dart points (see Figure 6). On the rest of the site, points from all time periods were found together in our collections.

\section{Other Chipped Stone Tools}

\section{Bifacial Knifes}

This biface has one straight lateral edge, and the other edge is curved slightly toward the distal end (Figure 8a), and is made from a non-local smoky gray chert. The artifact was a blade knocked off a larger core, because one side is flat where it had been removed, and the other has more flaking to thin it to its desired shape. There are impurities along the blade, causing flakes to snap off before they got to the middle of the piece. The distal and proximal ends have been broken. This blade was made to be hafted, because there is a shoulder on both sides, where the stem is formed by flaking along its side; $51 \mathrm{~mm}$ long, $36 \mathrm{~mm}$ wide, and $6 \mathrm{~mm}$ thick.

This biface is made from a non-local white flint chert, and was meant to be stemmed (Figure $8 \mathrm{~b}$ ). One of the lateral edges of the blade is straight, and the other is curved. It has been wll-thinned, with serrations along the sides, and the proximal end is broken. There is a slight shoulder, just before the break, that would indicate a stem was present before it 


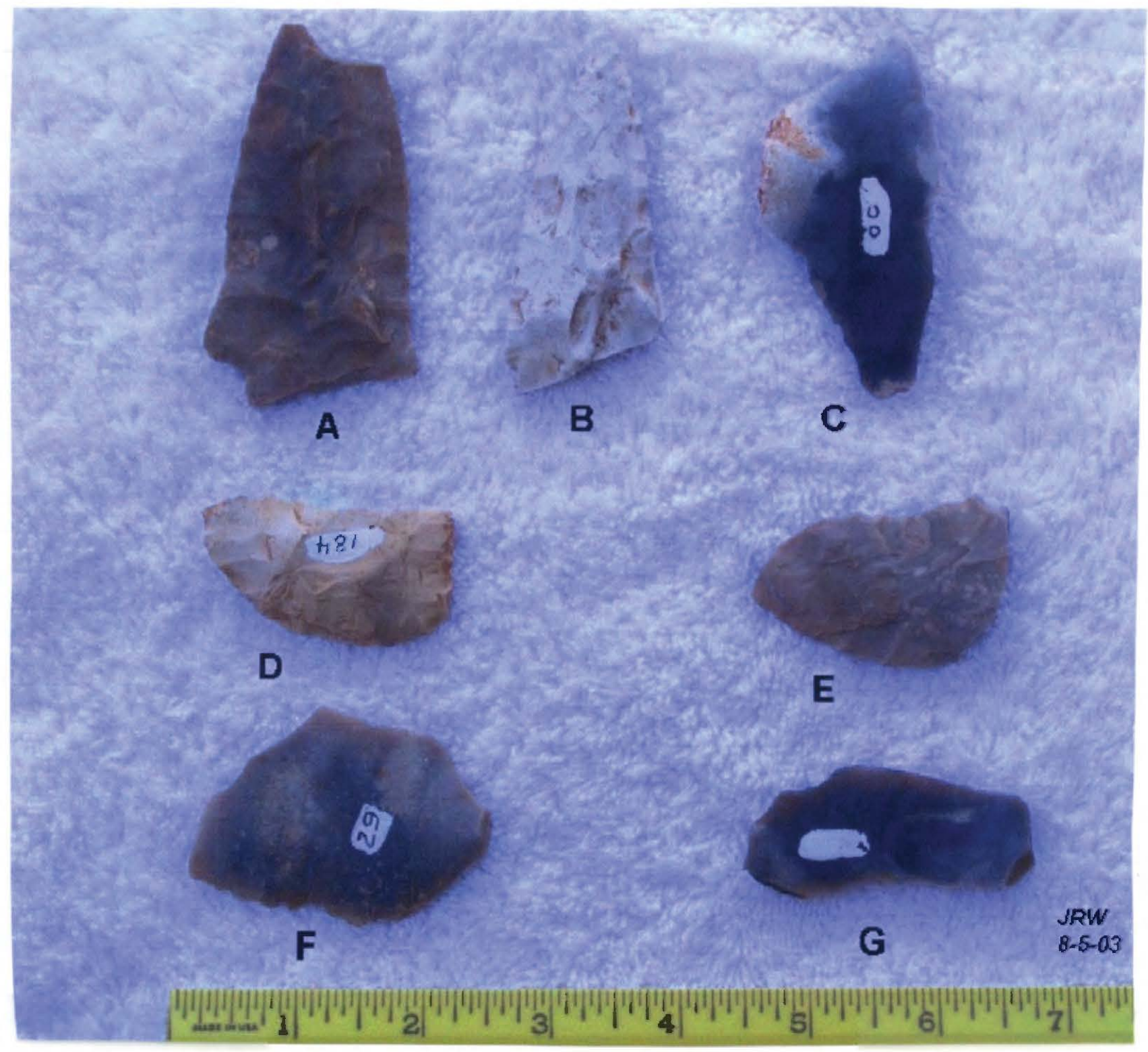

Figure 8. Bifacial Knifes from 41AN115.

was broken in manufacturing or during use; $80 \mathrm{~mm}$ long, $45 \mathrm{~mm}$ wide, and $9 \mathrm{~mm}$ thick.

This tool is a flake that has some cortex remaining on one side, it is almost black chert on one end, and a gray color on the other. This material likely came from the Edward Plateau, region, and has fine serrations along the bottom where a usable blade had been chipped (Figure 8c). This piece was worked on both sides along the blade and was not meant to be hafted. It is worked on only one side to thin it; $75 \mathrm{~mm}$ long, $40 \mathrm{~mm}$ wide, and $10 \mathrm{~mm}$ thick

This is a small bifacial knife (Figure 8d), with serrations on three sides for use. One of 
the lateral edges is straight, and the other is curved to a rounded point; the base is straight. It is made from a light gray chert not common in this area. Because the base is thinned, it may have been hafted on a handle; $52 \mathrm{~mm}$ long, $28 \mathrm{~mm}$ wide, and $5 \mathrm{~mm}$ thick.

This is a small triangular, bifacial knife that was removed off a larger piece. It has bcen worked on both lateral edges (Figure 8e), and the base was not modified. One of the edges is curved towards the distal end, and the other is concave at the base, then rounded near the distal end. This piece looks to have been held in the hand, for use, as the base has not been modified where it was snapped off. This tool is made from a non-local smoky gray chert; $51 \mathrm{~mm}$ long, $36 \mathrm{~mm}$ wide, and $6 \mathrm{~mm}$ thick.

This is a knife blade that was detached from a larger piece. Not much thinning was necessary for immediate use. There are fine serrations along two areas on one of the lateral edges, and the other edge was more coarsely-serrated, producing small teeth along the cutting surface (Figure $8 \mathrm{f}$ ). Raw material is a non-local smoky gray chert, and it may have been heat-treated; $60 \mathrm{~mm}$ long, $45 \mathrm{~mm}$ wide, and $5 \mathrm{~mm}$ thick.

This a small rectangular flake that has been serrated on three of the four sides (Figure $8 \mathrm{~g}$ ). The serrations were the only modification made to produce this tool for immediate use. The raw material is a non-local gray to almost black chert; $60 \mathrm{~mm} 27 \mathrm{~mm}$ and $4 \mathrm{~mm}$ thick.

\section{Scrapers}

This is a rectangular end scraper (Figure 9a) that has been chipped out of ferruginous sandstone, the only one made from this local material. It is a large piece that was knapped from a core, leaving one side of it flat, and the other thinned down to form a unifacial blade. There is a high plane down the center on each lateral side, and the back end is broken off straight; $45 \mathrm{~mm}$ long, $28 \mathrm{~mm}$ wide, and $11 \mathrm{~mm}$ thick.

This is an end scraper, made from a flake, with the cortex on one side (Figure 9b). This may be made on a piece of Central Texas gray chert. Only the top side of the flake has been worked to form this small unifacal blade; $32 \mathrm{~mm}$ long, $30 \mathrm{~mm}$ wide, and $9 \mathrm{~mm}$ thick.

This is the largest unifacial tool in the collection, having been chipped out of a small core of local red chert (Figure 9c). It has a blade on three sides, with the one side flat across the top. The scraper has been chipped on both sides to reduce the size, and to produce a blade for use. Both of the ends have been tapered to a rounded edge making the blade long and straight. This scraper is slick to the touch, perhaps from heat treatment for chipping; $53 \mathrm{~mm}$ long, $33 \mathrm{~mm}$ wide, and $12 \mathrm{~mm}$ thick

This is a teardrop-shaped end scraper made on a flake of non-local gray chert (Figure 9d). It was deliberately chipped to this shape, thinned all of the way around. The larger rounded end was thinned on both sides, but is thicker that the rest of the tool, and toward the pointed end it has been thinned down with small flakes, as if it were being serrated for 


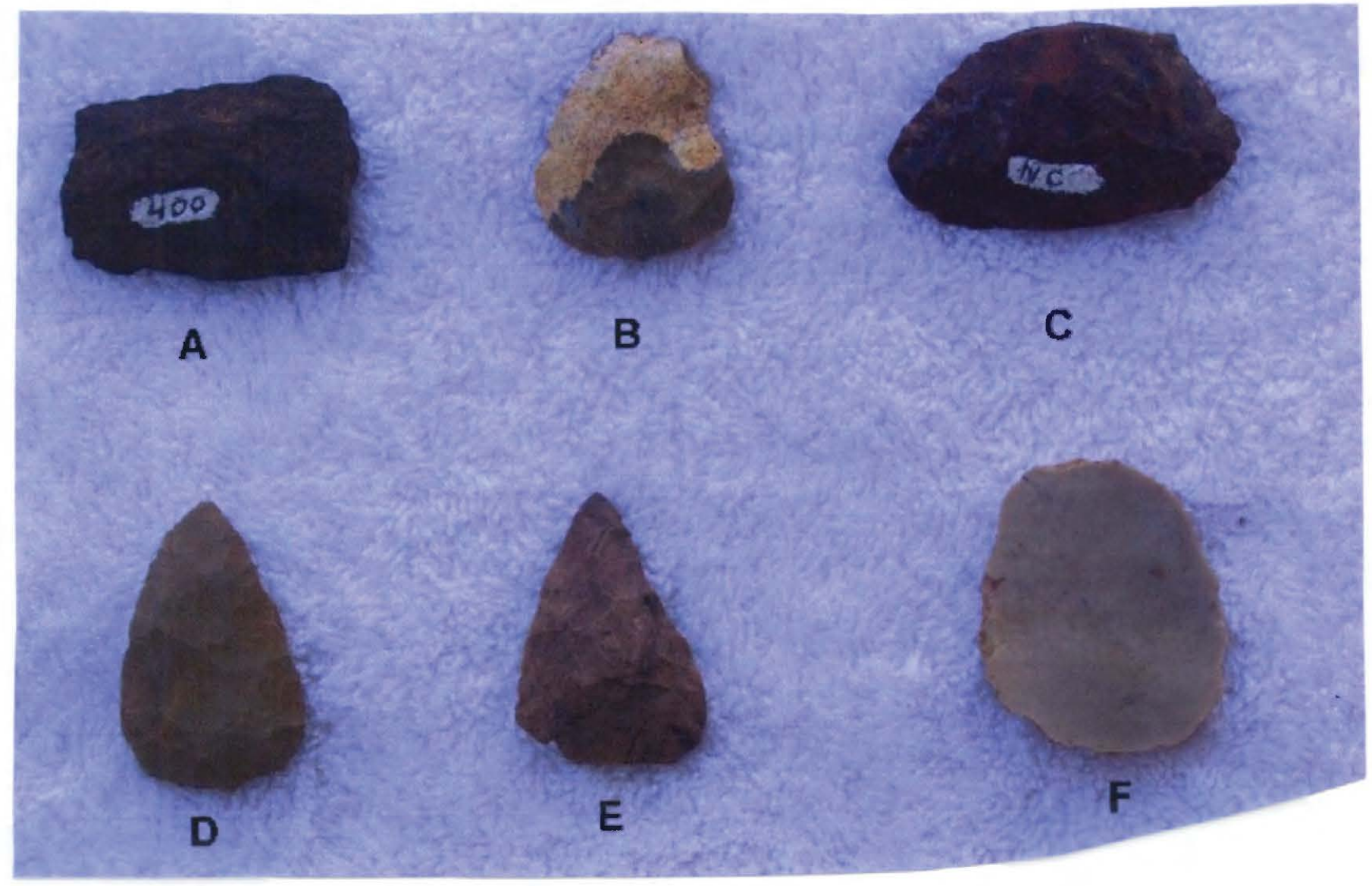

Figure 9, Scrapers from 41AN115.

another purpose; this piece is slick to the touch; $42 \mathrm{~mm}$ long, $27 \mathrm{~mm}$ wide, and $5 \mathrm{~mm}$ thick

This is another teardrop-shaped end scraper, more crude than the first, made out of a reddish-brown chert (Figure 9e). When the sides were being thinned, high places were left in the middle where the flakes snapped off. The wide edge is straight across where they formed the blade, and tapering to a point to the other end; $41 \mathrm{~mm}$ long $29 \mathrm{~mm}$ wide, and $10 \mathrm{~mm}$ thick.

This is a flake scraper that has three sides, and was fashioned to be almost round in shape (Figure 9f). It is on a non-local reddish-brown to light gray chert. The seraper has been thinned on only one side. The flakes taken off the piece are very small, not creating much modification; therefore, the edges are not very sharp, although the scraper is is very slick to the touch; $45 \mathrm{~mm}$ long, $35 \mathrm{~mm}$ wide, and $10 \mathrm{~mm}$ wide.

\section{Miscellaneous Chipped Stone Tools}

Graver: a small thin flake with a sharp spur made on one side for cutting or engraving (Figure 10a). This artifact is made from a local gray chert . 


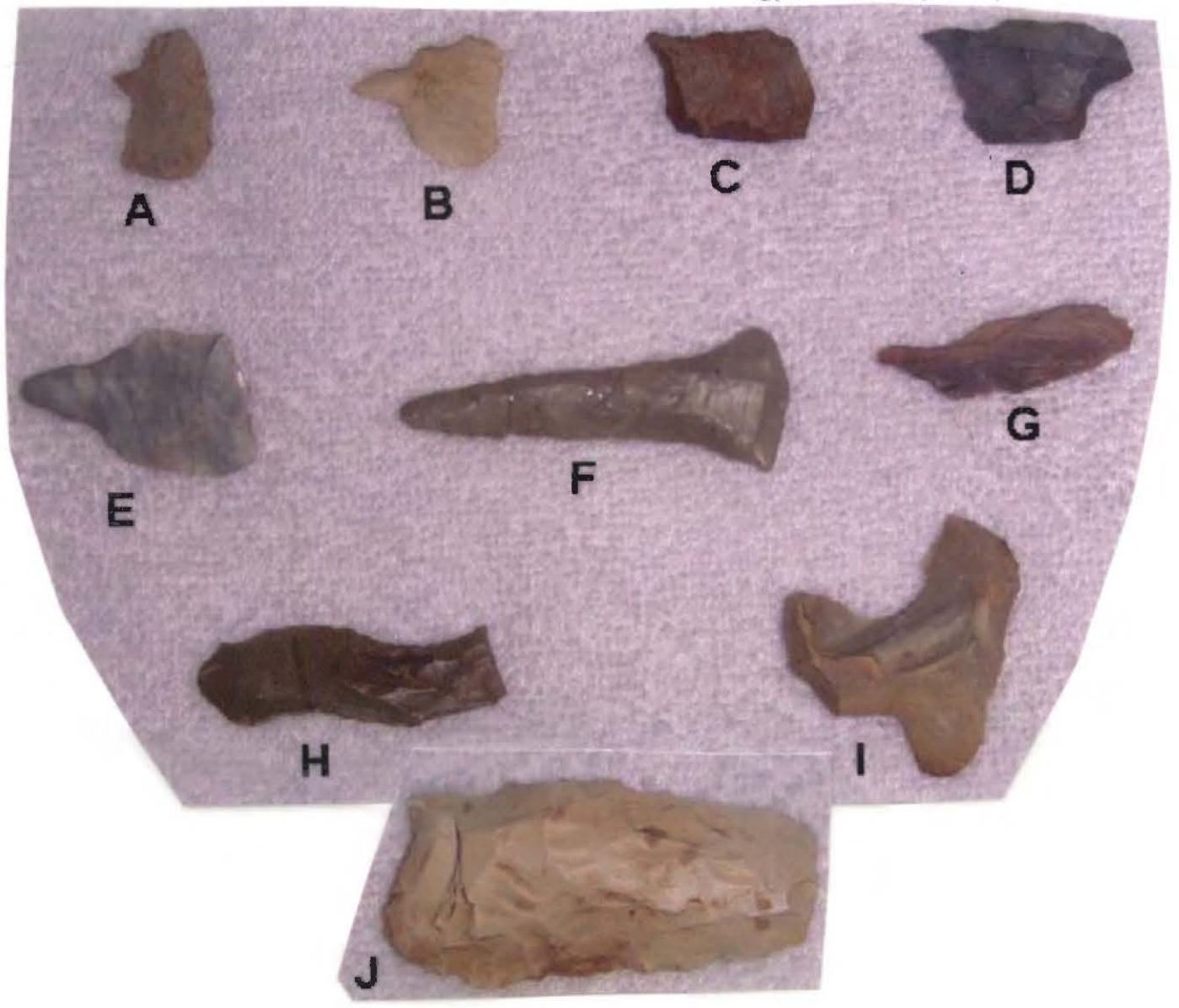

Figure 10. Miscellaneous chipped stone tools.

Graver: small thin flake with one sharp protrusion on one side (Figure 10b). This tool is made from a light gray chert.

Graver: a thin flake (Figure 10c), made of a reddish-brown chert with one spur along the top. The very tip is broken.

Graver: a flake with one sharp protrusion (Figure 10d) that has a ridge running from one side along, and forming, the spur for cutting or engraving. This artifact is made from a dark gray chert.

Perforator/drill: this artifact is made on a flake that has been worked on both sides; one side was thinned, and the bit was worked on both sides to form a tapered point (Figure $10 \mathrm{e})$. The base is square and has been thinned, probably for hafting. The sides are straight until the bit starts tapering down to a point. This is made from a gray flint, possibly from the Edwards Plateau.

This is an artifact that has a long tapering bit, wedged-shaped, for use as a drill (Figure 10f). The base has been thinned, probably for hafting, and the tool has been reworked from a projectile point. This material is non-local gray chert, and is slick to the touch. The base of the drill is small, and the remainder is the tapered blade and the bit. This drill 
was broken approximately one third of the way from the distal end, but both pieces were recovered in our collections.

Perforator/drill: this flake artifact is chipped from petrified wood, and has been thinned on one side (Figure 10g); the other side is smooth where it came off a larger piece. There is one long bit, fashioned at one end, with the area just behind the point flat to apply pressure for use.

Spokshave: this is a small S-shaped artifact that has small serrations on opposite sides of the tool for scraping purposes (Figure 10h). The material is a brown chert, very slick to the feel, with some thinning on one side, while the other side is smooth from where it was detached from a larger flake.

Spokehave: it has a Y-shaped configuration, with flaking on both sides, to create a working edge inside the Y (Figure 10i). The tool is made from a non-local tan-colored chert.

Saw: this is a small rectangular core tool, with chipping on all four sides (Figure 10j). The cross section is diamond-shaped, and is chipped from a creamy white piece of chert. The distal and proximal ends are thinned but blunt, and the lateral sides have coarse serrations along both edges, forming small teeth for use. This lithic raw material is slick to the touch, and may have been heat treated for chipping.

\section{Chert Blanks}

The first chert blank is an oval-shaped piece that has been thinned on both sides (Figure 11a), and around the edges, to form a bifacial blank for later use. This chert is light to dark gray in color, and looks to be from the Edwards Plateau area of Central Texas. On one side, there is a small band of cortex, but otherwise is has been thinned and the cortex removed during knapping; $71 \mathrm{~mm}$ long, $50 \mathrm{~mm}$ wide, and $10 \mathrm{~mm}$ thick.

This piece, a creamy gray chert, is straight across the bottom and sides are straight, and has a rounded tip (Figure $11 \mathrm{~b}$ ). The raw material is slick and may have been fire-treated. This blank has been thinned on both sides, and the edges has been flaked for further reduction in size and weight; $75 \mathrm{~mm}$ long, $52 \mathrm{~mm}$ wide, and $10 \mathrm{~mm}$ thick

This blank is straight across the bottom and sides, and the distal end is rounded (Figure 11c). It is made from a gray chert, possibly from the Edwards Plateau, that has small white impurities on both sides. This piece has been well-thinned on both sides, and the edges have also been flaked to create the blade. There is no cortex on this piece, and it has a slick feel, probably because it was heat-treated; $101 \mathrm{~mm}$ long, $51 \mathrm{~mm}$ wide, and 14 mm thick

This blank is straight across the bottom and one of the sides, while the other is slightly curved towards the rounded proximal end (Figure 11d). This material is a light gray chert 


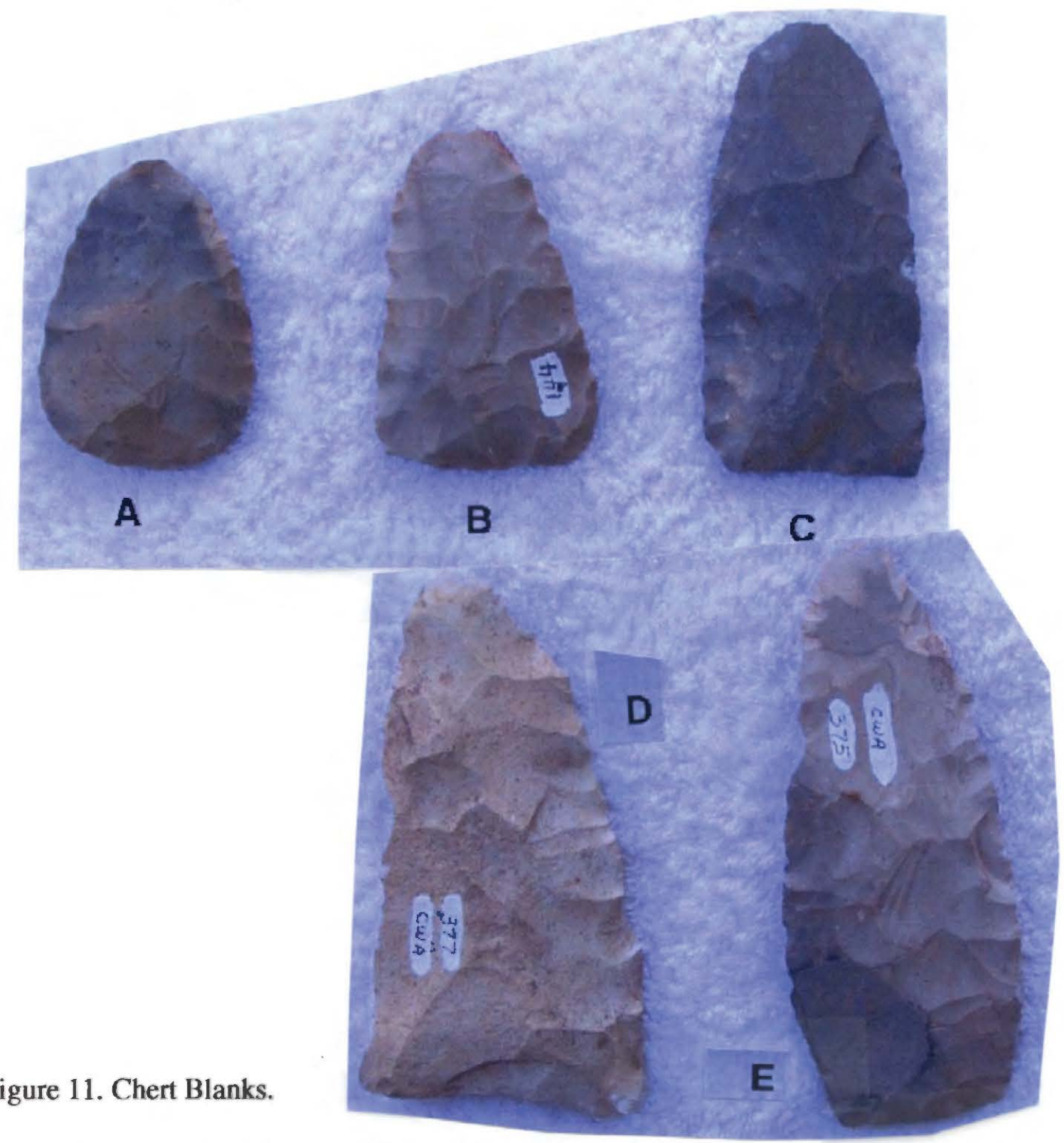

(probably from the Edwards Plateau), almost white in color, and has been thinned on both sides. The edges are thinned but not as much as the first three specimens described in this section; $120 \mathrm{~mm}$ long, $60 \mathrm{~mm}$ wide, and $20 \mathrm{~mm}$ thick.

This blank has been thinned on one side, and the other side has a ridge running down the entire length of the blade (Figure 11e). The base is straight, and the sides are roughly parallel, and they been chipped to create a rounded proximal end. The material is gray chert, likely from the Edwards Plateau area. There are some impurities in two places on one side, and it has a slick feel to the touch; $130 \mathrm{~mm}$ long, $60 \mathrm{~mm}$ wide, and $15 \mathrm{~mm}$ thick.

\section{Petrified Wood Tools}

End scraper (Figure 12a): a small piece of petrified wood that has been worked to a round 


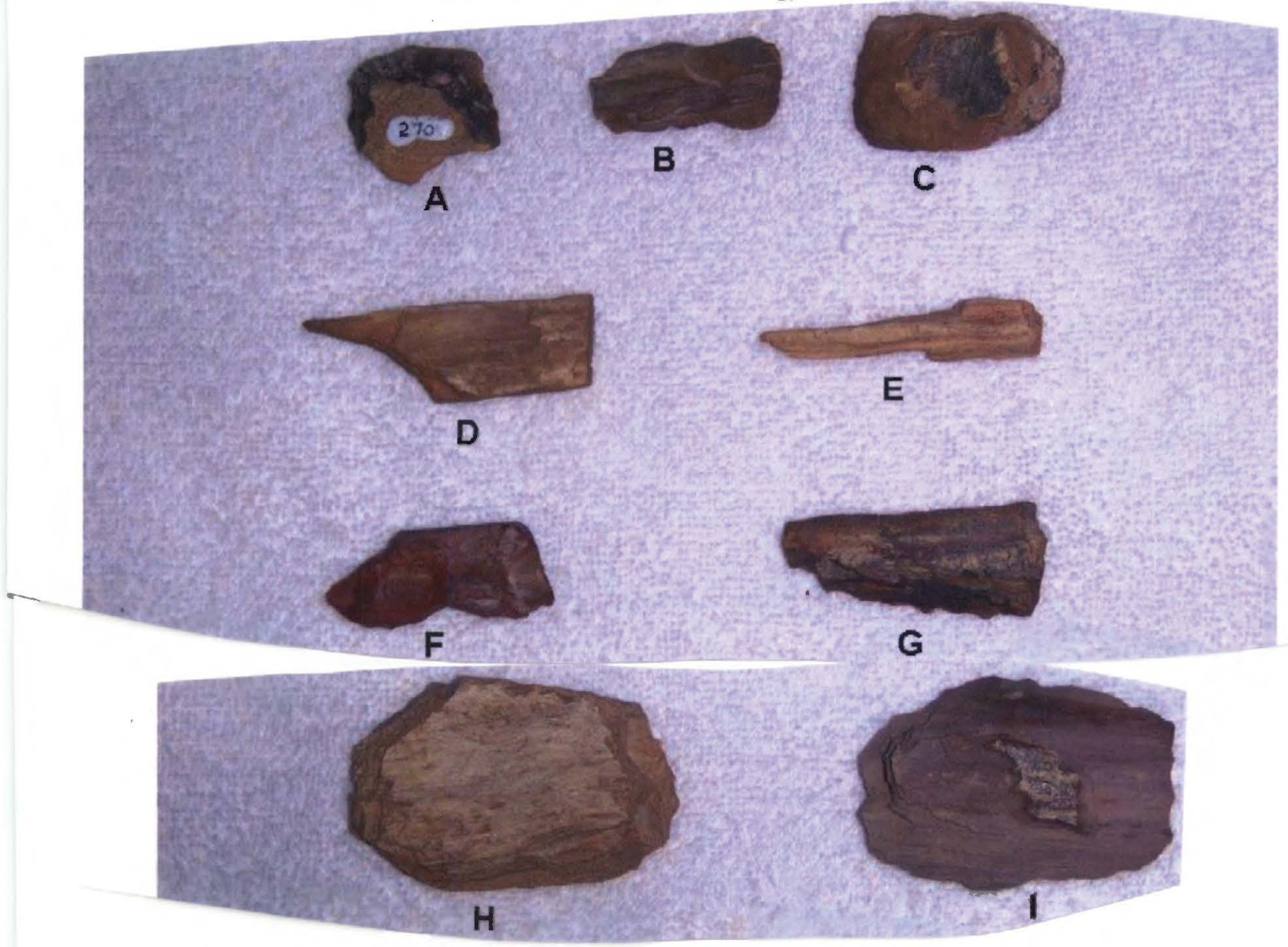

Figure 12. Petrified Wood tools from 41 AN115.

shape, with flakes removed almost all the way around it. This piece is diamond-shaped in the middle, with a blade on both sides that runs almost three-fourths of the way around the tool. There is cortex on one side, except for the flaking on the blade, and the other side has flakes taken off by thinning.

This is an end scraper that is made from a flake with a bit on one end (Figure 12b). It is rectangular, with an unifacial working edge on one end, and the other straight across where it was detached from the larger piece. The scraper edge is steep and blunted where it has been step flaked.

This is an end scraper, made from a small core piece, with a unifacial working edge on one end (Figure 12c). This piece is approximately $14 \mathrm{~mm}$ thick, and has cortex on the top and bottom. The scraper is roughly parallel-shaped, with some flaking around each side, and across the proximal end. The bit is steep with flakes taken off one side to form a dull 
edge.

Punch: a thin rectangular piece of petrified wood with both sides and the bottom squared off, and a long thin point flakcd on the other end (Figure 12d). The point is broken at the end.

Punch: a small piece of petrified wood that is almost square at the bottom. There is stepflaking beginning part way up the point all the way to its tip (Figure 12e).

Small knife: a small flake that has a squared-off bottom and to near the top, where the edge begins to angle down to a point (Figure 12f). The blade was formed by removing a few flaked from the bottom edge. This tool was probably held in the hand, and was not meant for hafting.

Knife: a small piece of petrified wood, squared off along the back, and along the top, with a worked edge from the front to the back of the tool (Figure 12g). Only a few flakes were removed on one side to form the working edge. This was held in the hand, and not meant for hafting.

Chopper: this is a core tool that has a chipped edge on one end for cutting or chopping, and it has cortex on both sides (Figure 12h). There is flaking on all four sides, for thinning, and it has been modified to fit the hand. The tool blade is flaked on both sides, forming a rounded edge.

Chopper: a core tool that has been flaked on all four sides, with one end brought to a sharp edge for cutting or chopping (Figure 12i). There is cortex present on one side, with the rest removed in the thinning and shaping of the tool. The tool blade was formed straight across the top, with the bottom side angled to form a beveled edge.

\section{Final Comments on Chipped Stone Tools:}

After analyzing the collection of chipped stone artifacts, we looked at three questions: (1) identification of material sources; (2) methods of reduction; and (3) whether artifacts were produced on site or brought in.

We went to several locations in Anderson County, Texas, looking for and collecting lithic raw material to see if there was a source or several sources that were used for making of chipped artifacts at 4IAN115. The material we brought back was broken up and compared to the lithic raw material we found at this particular site. The different types of materials we found in our search consisted of quartzite, fine and coarse grained, petrified wood, cherts of different kinds, and a material that looked like white glass. This is not unlike the same range of material we found throughout the site, leading us to conclude that most of the tools were made from materials that were there naturally, or brought in whole, or as fragments that was broken down during tool manufacture. We did not find chert materials that resembled the materials some of the dart points, scrapers, and 
knives were made of.

Methods of reduction ranged from hard hammer, where large pieces were broken apart, to soft hammer reduction, where there were bulbs of percussion on one end of the flake, to small flakes produced by a flaking tool in shaping the end result. These were mixed and scattered from one end of the site to the other.

Artifacts produced on site tended to be made from local lithic raw materials, such as quartzite, some cherts, and petrified wood. Petrified wood could be collected throughout the area, as it is scattered across Anderson County. Good quality chert is not available here, and no major sources in the area have been located.

The core tools seemed to be chipped out of this local material, whereas the earlier dart points, and some flake knives in particular, were brought in from the Edwards Plateau and the Georgetown, Texas, areas of Central Texas. Among the exhausted cores, however, 58 were of local materials, and only three cores were on non-local lithics. The conclusion we reached was that the earlier points and some earlier tools were of chert materials that were brought in from some distance, but that this pattern of lithic raw material use began to change. As time went on, the people occupying 41AN1 15 began to use local raw materials for their needs..

\section{GROUND STONE TOOLS}

Most of the ground stone tools we found at 41AN115 seemed to be strictly for utilitarian purposes and not produced in a style associated with a particular culture. Some of the modifications are slight, with little effort, or time being spent to make the tool, while other tools_-possibly because of the length of time they were meant to be used - were shaped more completely. Several of the tools were used as multi-purpose ground stone tools.

The majority of the ground stone tools were used for milling and grinding purposes, possibly in food preparation. The types of material represented in this collection are: hematite; ironstone or ferruginous sandstone; coarse and fine-grained sandstone; coarse and fine grained quartzite; chert; and petrified wood (Table 2).

Table 2. Raw materials used for the Ground stone tools.

\begin{tabular}{|c|c|c|c|c|c|c|c|}
\hline & \multirow{2}{*}{ Chert } & \multirow{2}{*}{ Quartzite } & \multicolumn{2}{|c|}{ Petrified SS } & \multirow{2}{*}{$\begin{array}{l}\text { SS } \\
\text { Coarse }\end{array}$} & \multirow{2}{*}{$\begin{array}{l}\text { Hematite/ } \\
\text { FSS }\end{array}$} & \multirow{2}{*}{ Unknown } \\
\hline & & & Wood & Fine & & & \\
\hline Gouge & 1 & & 1 & 6 & & & \\
\hline Handaxe & & & 1 & 3 & & 5 & \\
\hline Nutting & & 2 & & & 22 & & \\
\hline \multicolumn{8}{|l|}{ Stone } \\
\hline Anvil & & 2 & & & 27 & & \\
\hline \multicolumn{8}{|l|}{ Stone } \\
\hline Mano & & 18 & & & & 36 & 4 \\
\hline
\end{tabular}


Table 2. Raw materials used for the Ground stone tools, cont.

\begin{tabular}{|c|c|c|c|c|c|c|c|}
\hline & \multirow[t]{2}{*}{ Chert } & \multirow[t]{2}{*}{ Quartzite } & \multicolumn{2}{|c|}{ Petrified SS } & \multirow{2}{*}{$\begin{array}{l}\text { SS } \\
\text { Coarse }\end{array}$} & \multirow{2}{*}{$\begin{array}{l}\text { Hematite/ } \\
\text { FSS }\end{array}$} & \multirow[t]{2}{*}{ Unknown } \\
\hline & & & Wood & Fine & & & \\
\hline Metate & & & & & 5 & & \\
\hline Abrading & & & & 22 & 9 & & \\
\hline Stone & & & & & & & \\
\hline Hammer & & 25 & & & & & \\
\hline Stone & & & & & & & \\
\hline Modified & & 5 & & 5 & 2 & & \\
\hline Stone & & & & & & & \\
\hline Total & 1 & 52 & 2 & 36 & 65 & 41 & 4 \\
\hline
\end{tabular}

SS=sandstone; FSS=ferruginous sandstone

The modification on these 201 tools (Table 3 ) represents a combination of intentional shaping to produce convex, concave, pitted, grooved, incised, and chipped surfaces or edges. We broke these tools down into the following categories: pecking and abrading surfaces; chipped surfaces; pitted surfaces; and smoothed and incised tool surfaces.

Table 3. Description of Ground stone Tools.

Type of Tool No. of Specimens

\begin{tabular}{lr}
\hline Gouge & 8 \\
Hand Axe & 9 \\
Nutting Stone & 24 \\
Anvil Stone & 29 \\
Mano & 58 \\
Metate & 5 \\
Abrading Stone & 31 \\
Hammerstone & 25 \\
Modified stone & 12 \\
\hline
\end{tabular}

Total

The ground stone tools that we describe here are to inform the reader about the type of tools that were found at 41ANI15, the range of lithic raw materials that were used, and an idea of the scope of the tool kit that the inhabitations left behind. 


\section{Stone Axe Heads}

Large single-grooved axe head (Figure 13a), produced from a reddish-brown hematite. This piece is nicely worked on one side of the blade, having a smooth patina, but with pitted and rough spots on the other side. The bit meets at the blade end to form a point, while the wedge-shaped poll end has two straight sides that come together in the back. There is a groove that encircles the axe head; on one side the groove is rough and marked by pecking. This tool looks well-used, because of several fractures and scratches on the bit and blade. Both sides of the blade are convex in shape, and the body in cross-section is diamond-shaped. The width across is $6 \mathrm{~cm}$ at the poll, and the axe head is $16 \mathrm{~cm}$ long.
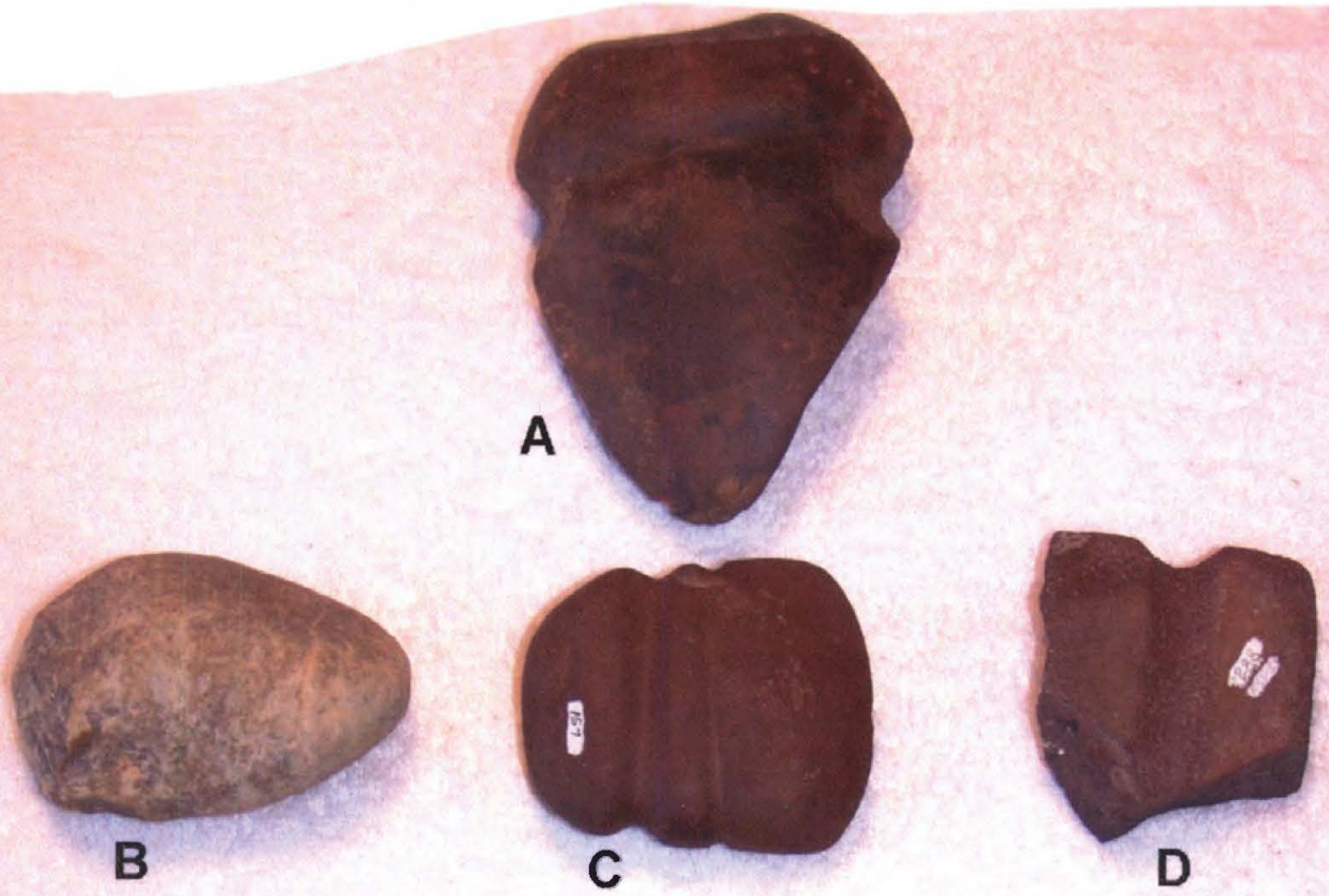

Figure 13. Axes from 41AN115. 
Unfinished celt-like tool: made from a greenstone rock, with white inclusions (Figure 13b). The only modifications are flakes removed by direct percussion off both sides on the bit end, forming the cutting edge. The rest of the stone is in its natural condition, larger on one end, and tapering to a rounded end on the other. The stone probably would have continued to be chipped to form the blade, and then ground smooth to produce a celt. The stone is $10 \mathrm{~cm}$ in length, $5 \mathrm{~cm}$ on the side at the thickest part, and $7 \mathrm{~cm}$ wide.

Double grooved axe head (Figure 13c) made from a red hematite. It is small, and well made, with scars on the poll end and one scar where the two grooves are on one side. On one side, both grooves are still visible, but on the other side of the blade, only one groove is present next to the poll. Both of the blades are smoothed down to the semi-rounded bit, with the poll end rounded on the head. The axe head is $9 \mathrm{~cm}$ long, with a maximum thickness of $4 \mathrm{~cm}$.

Single grooved axe head, broken, made from ferruginous sandstone. The blade end has been broken, next to the groove, and the poll has one side broken next to the groove (Figure 13d). This axe head was pecked and abraded into shape with one groove that encircles the axe. The axe head on the poll end was rectangular with flat sides, but because the blade is broken off, we do not know the shape of the cutting edge. The flat surface of the poll end was used, as shown by small flake scars there. The existing piece is $7 \mathrm{~cm}$ long and $3 \mathrm{~cm}$ wide.

Unfinished axe perform made from ferruginous sandstone (Figure 13e). The entire surface has small peck marks from shaping. The axe head is rectangular, with the widest part in the middle, and the blades have been thinned to a rounded edge. It looks as if the manufacture of the axe started at the edge of the blade and proceeded up the lateral edges toward the poll end. This axe perform is important because it shows how these artifacts were manufactured, first being pecked into shape, then abraded into the desired finished tool. This perform is $18 \mathrm{~cm}$ long, and $5 \mathrm{~cm}$ thick at the poll end.

\section{Gouges}

Gouge chipped out of fine-grained ferruginous sandstone, with a steep working edge (Figure 14a). The blade is the widest part of the tool and tapers slightly to the proximal end. There are flake scars over most of the tool, and the bottom is slick from use; $8 \mathrm{~cm}$ long $5 \mathrm{~cm}$ wide, and $3.5 \mathrm{~cm}$ thick

Gouge: made from a gray chert possibly from the Edwards Plateau area; it is the only tool of this kind we found produced out of chert (Figure 14b). The blade is straight and has a steep working edge. There is a ridge running down the length of the gouge with a slight tapering of the lateral edges toward the proximal end; $8 \mathrm{~cm}$ long, $4.5 \mathrm{~cm}$ wide, and $3 \mathrm{~cm}$ thick.

Gouge: made from a fine-grained ferruginous sandstone (Figure 14c); it is lat across the top and tapers toward the proximal end. The blade is steep, and the lateral edges are chipped to beveled edges. The top of the tool is straight from one side to another, and the 


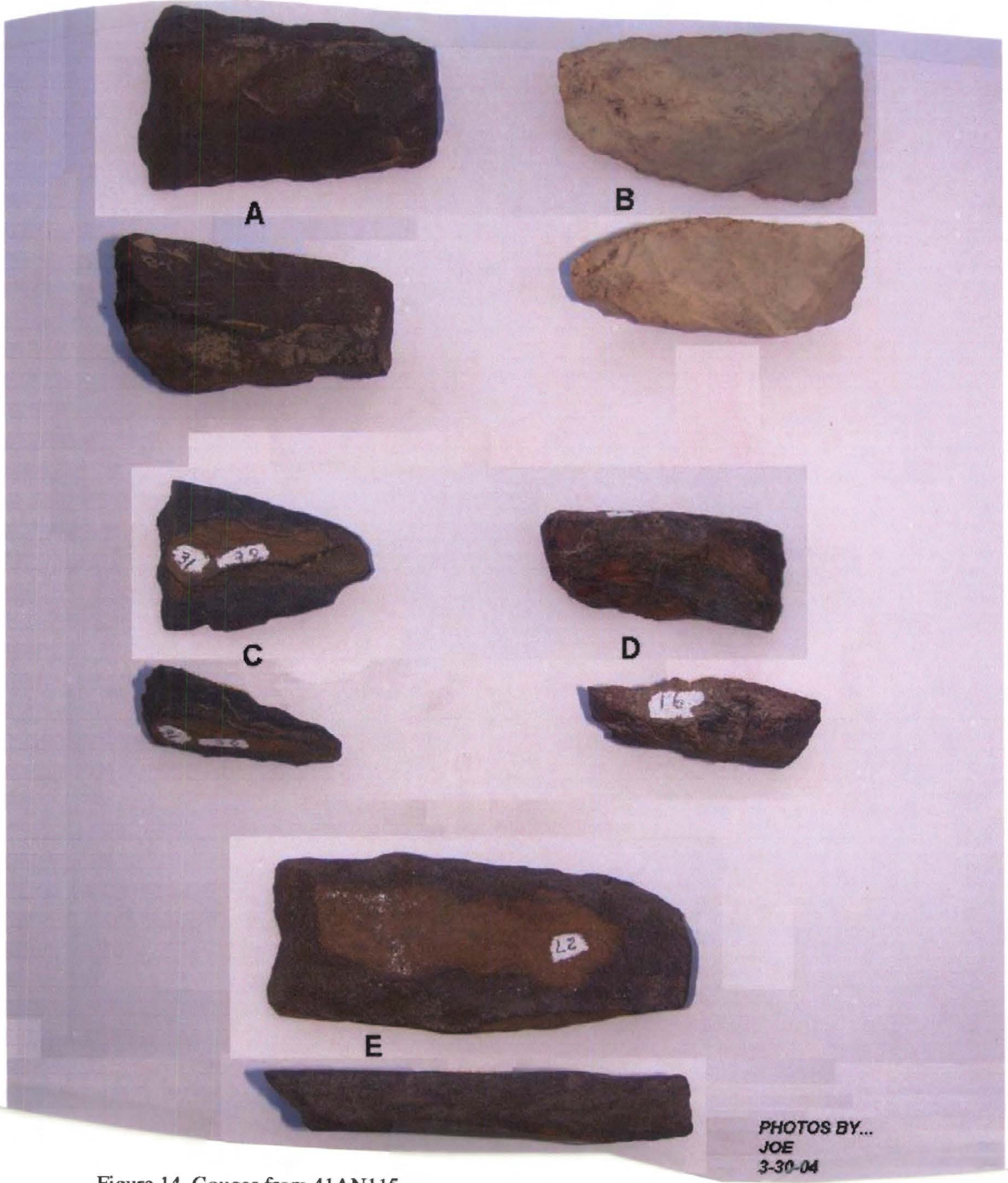

Figure 14. Gouges from 41AN115. 
bottom has a very smooth feel from use; $6 \mathrm{~cm}$ long, $4 \mathrm{~cm}$ wide, and $1.5 \mathrm{~cm}$ thick.

Gouge, chipped out of petrified wood (Figure 14d). It is rectangular with a steep edge that forms a straight blade. There are irregular flaking scars over the body of the tool and the bottom is smooth from use; $7 \mathrm{~cm}$ long, $3 \mathrm{~cm}$ wide, and $2 \mathrm{~cm}$ thick

Gouge, made from a fine-grained ferruginous sandstone, flat on top with a steep edge that forms a straight working edge (Figure 14e). This tool tapers toward the proximal end, with a bottom slick from use; $12 \mathrm{~cm}$ long, $4.5 \mathrm{~cm}$ wide, and $1.5 \mathrm{~cm}$ thick.

\section{Manos, Metates, and Abrading Stones}

Mano: produced from a hematite/ferruginous sandstone, smoothed from use on both sides, with one side having a slight depression in the center of one side (Figure 15a). This is one of several manos found where we think grain or whatever plant remains they were grinding was first smashed and then ground down to a powder.

Mano: made from a quartz cobble, roughly rectangular (Figure 15b), and was used on both sides.

Abrading stone: a convex shape from use (Figure 15c); both sides are rounded in shape, beginning at the middle of each side. The stone is course-grained sandstone with wear also on both ends.

Abrading stone: made from a coarse sandstone, used on both sides, but rough to the touch. There are concave depressions on both sides, wearing it thin from use (Figure $15 d)$. In addition, the edges along the sides had been rounded from use.

Metate: broken in half, and made from a fine-grained sandstone, with use on both sides (Figure 15e). This tool was worn down and thinnest in the middle, eventually leading to breakage of the tool down its center. There was intentional modification on the sides, creating a smooth rounded shape.

\section{Tools with Pitted Surfaces}

Hematite/ferruginous sandstone mano, with a slight depression in the center (Figure 16a). This mano is worked only on one side. Thew pitted surface in the center probably marks where grain was struck and then processed by grinding it against a metate.

Nutting stone, with one depression on each side. This is made from a coarse-grained sandstone, where smooth pits were worn over time, possibly from cracking nuts of some kind (Figure 16b). This tool could have been held in the hand, because of its size, while striking the nut.

Multi-pitted stone, roughly square in shape. The top side has two pits in it, while the bottom and the sides each have a single pit (Figure 16c). This is made from a coarse- 
Journal of Northeast Texas Archaeology, No. 21 (2005)
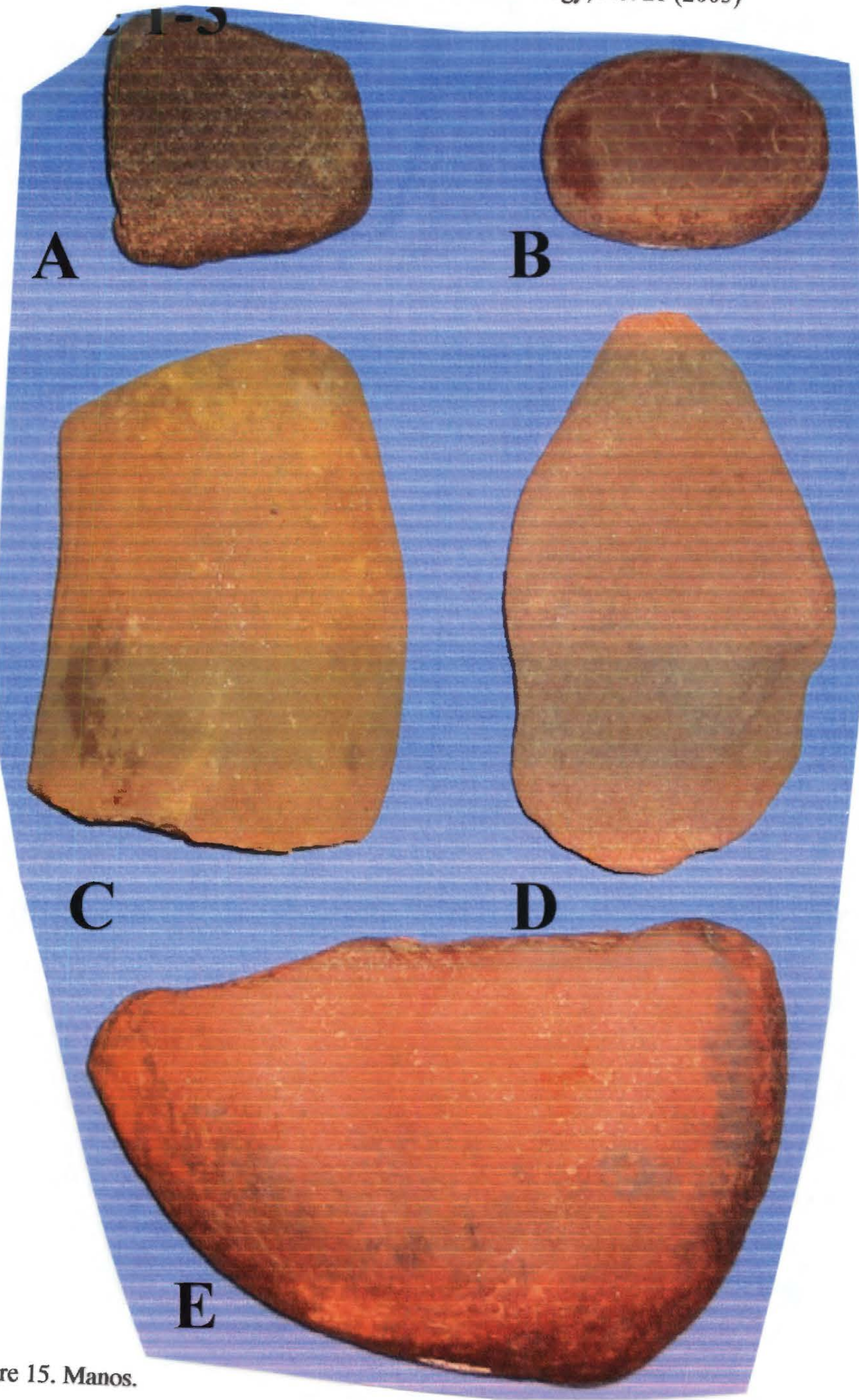


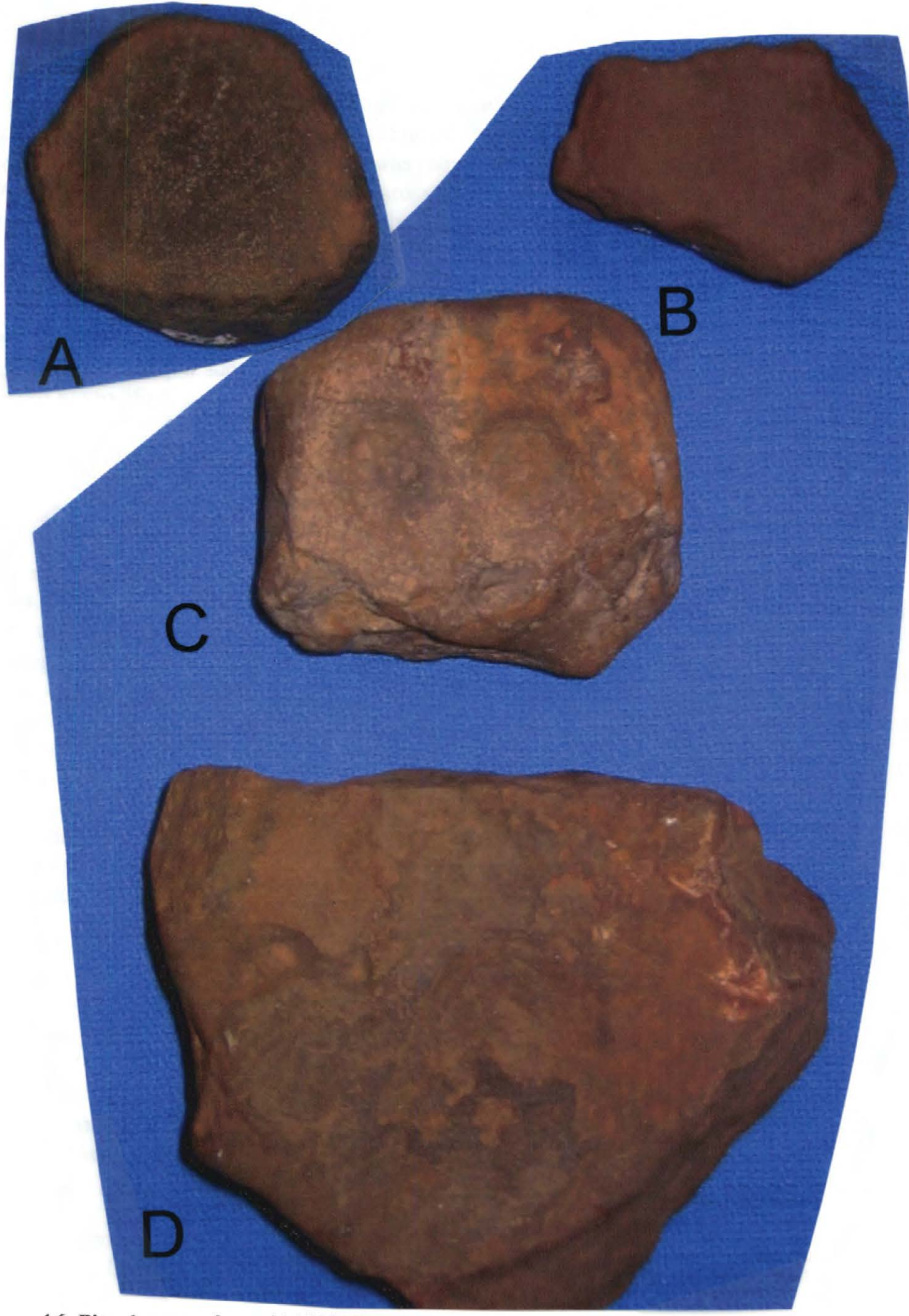

Figure 16. Pitted stones from 41AN115. 
grained sandstone. The tool could have been held in the hand, or placed on the ground for use.

Large flat anvil stone, made from a fine-grained sandstone. It has multiple pits, irregular in shape, from indirect percussion blows (Figure 16d). Most are not very deep, leaving small scars where the cortex of the rock was removed during use. The anvil stones at 4 I AN1 15 were larger and made from a harder sandstone than were the nutting stones, which were communally small enough to be held in the hand while using.

\section{Chipped Hand Axes and Cutting Tools}

Small fine-grained sandstone cutting tool, with the blade formed from chipping on one side to create a steep blade (Figure 17a). The back end is tapered, and the rest of the tool was left unmodified.

Small fine-grained sandstone cutting tool, with the edges chipped on one side to form a straight and square blade (Figure 17b). The other end has been modified to fit the palm of the hand.

I.arger hand axe, made from fine-grained sandstone, with the blade chipped straight across by taking two flakes off one side, and one off the other (Figure 17c). The back end of the tool is thicker than the rest of the piece, and straight across, with the lateral edges forming a wedge at the cutting edge.

Square flat hand axe, with an edge formed on one corner by removing one flake off each side (Figure 17d). The stone is unaltered except for the blade.

Ferruginous sandstone hand axe, for use on larger tasks. The cutting edge is straight across the face of the tool, with one set of flakes removed from each side to form the blade (Figure 17e). The back end was flaked at an angle to fit the hand, otherwise the stone is unaltered.

\section{Miscellaneous Ground Stone Tools and Hammerstone}

Polishing Stone, made from a small round and highly polished quartz pebble (Figure 18a). This stone was smoothed on both sides, and along the edges.

Incised flat bar-shaped piece of sandstone bar with straight ends (Figure 18b), with lines etched on all four sides. The incised lines run straight up and down across the artifact, but their purpose is unknown. The edges of the stone are worn down, as if this object was carried for a period of time.

Quartzite hammerstone, with both ends battered, causing the removal of the cortex (Figure 18c). Quartzite was the preferred stone for hammerstone use, apparently because of its hardness. 
Journal of Northeast Texas Archaeology, No. 21 (2005)

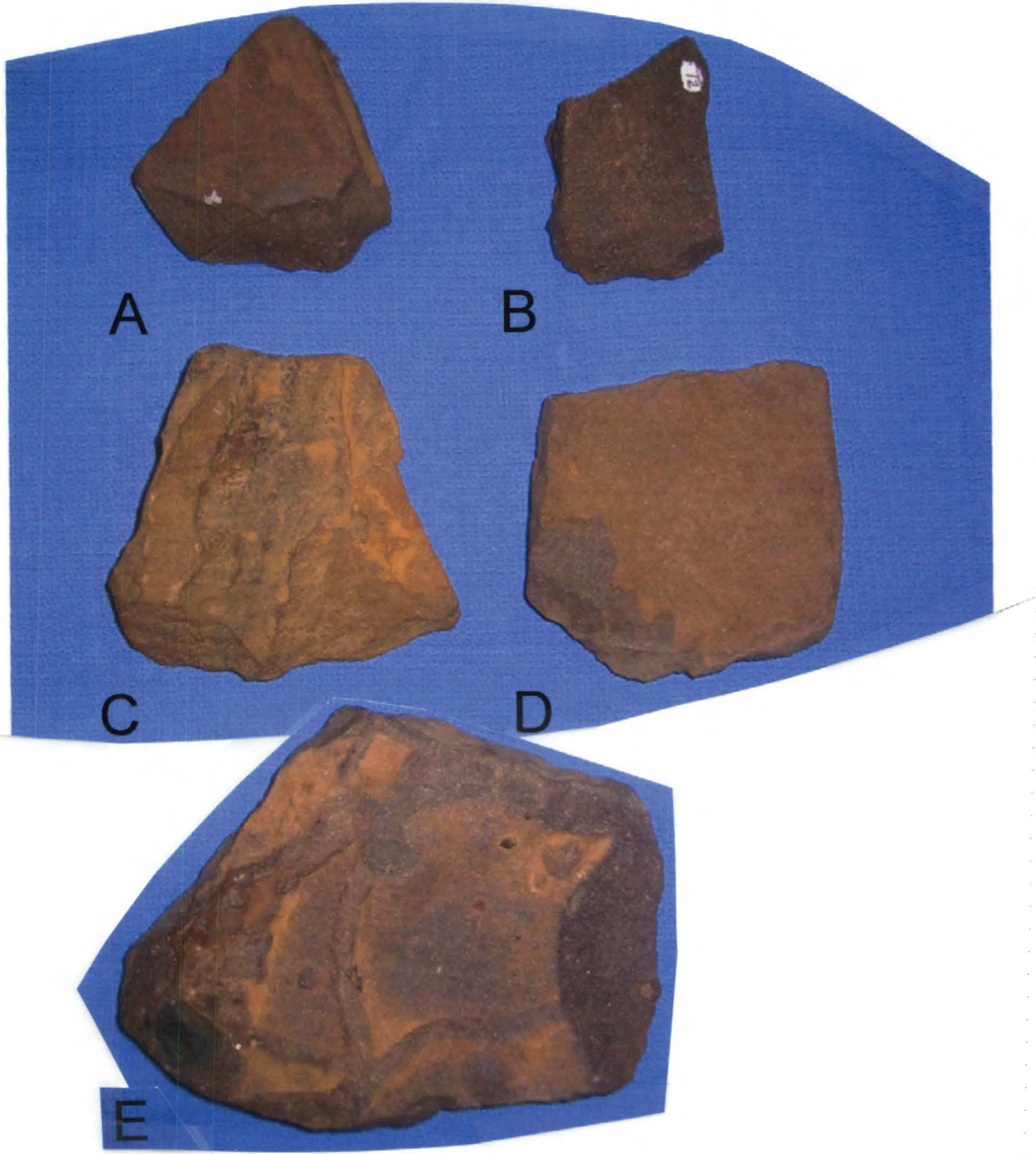

Figure 17. Stone cutting tools. 
Journal of Northeast Texas Archaeology, No. 21 (2005)

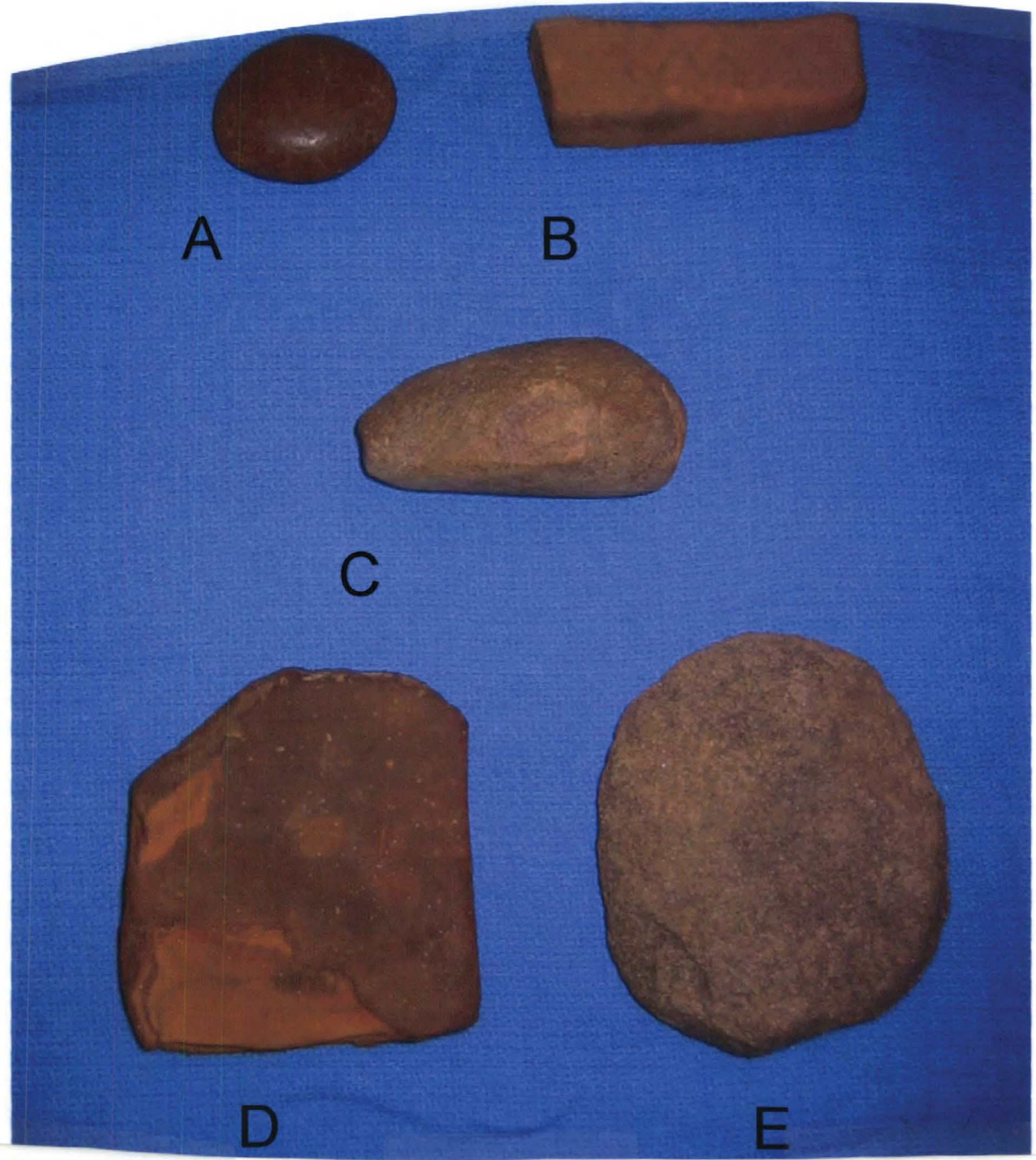

Figure 18. Miscellaneous ground stone tools. 
Unknown tool made from a fine-grained sandstone. The artifact is intentionally shaped and ground smooth on both sides (Figure 18d). Part of the cortex has been removed, probably by time, the sides are very smooth, and one corner is missing. This tool is too large to be used as a mano, and there are no grinding marks of signs of percussion flaking.

Unknown type of ground stone tool (perhaps unfinished), flat, and rounded in shape, produced from a coarse sandstone (Figure 18e). The sides are rounded, but the coarseness of the stone feels rough to the touch.

\section{Discussion and Summary of Ground Stone Tools}

A total of 201 ground stone tools were collected and identified at the site that may have been used during the Paleoindian, Archaic, and Woodland period occupations. The tools were not made in any particular style, or had a distinctive form, and were intended for every-day or mundane use. Material for the tools was found locally in the outcroppings, and creek beds in the vicinity of 41AN115.

Coarse and fine-grained sandstone made up the largest percentage of the stone tools that were used for milling and grinding, pitted stones, and abraders. One sandstone artifact was unique because it was a small bar-shaped piece, flat on both sides and rectangular, and straight ines were incised on the top and bottom and the sides (see Figure $18 b)$.

Because of its durability, quartzite was used extensively as heated rock to cook with, for dart points, manos, and hammerstones. Several unmodified cobbles were also found at the site.

Petrified wood was scattered throughout the site, where it was broken and chipped into mainly cutting tools.

The ground stone tools were not found in any single part of the site, perhaps because some of the tools used by one group may have been picked up and moved around for use by another. There were two caches of milling tools buried together at 41AN115, probably by someone who intended to use them again.

Burnt rock was identified throughout the site, sometimes several pieces in one location, leaving us to believe that some kind of fire pit was in use there. Because of the asphalt company scattering and removing soil in digging up the sand, pieces of burnt rock were found in various places across 41AN115.

\section{ARTIFACTS OF CLAY: WOODLAND PERIOD POTTERY SHERDS}

Sandy paste pottery sherd, representing part of the vessel rim, slightly curved (Figure 19a); sandy brown color, and gritty to the touch. This piece is undecorated; $5 \mathrm{~mm}$ thick. 

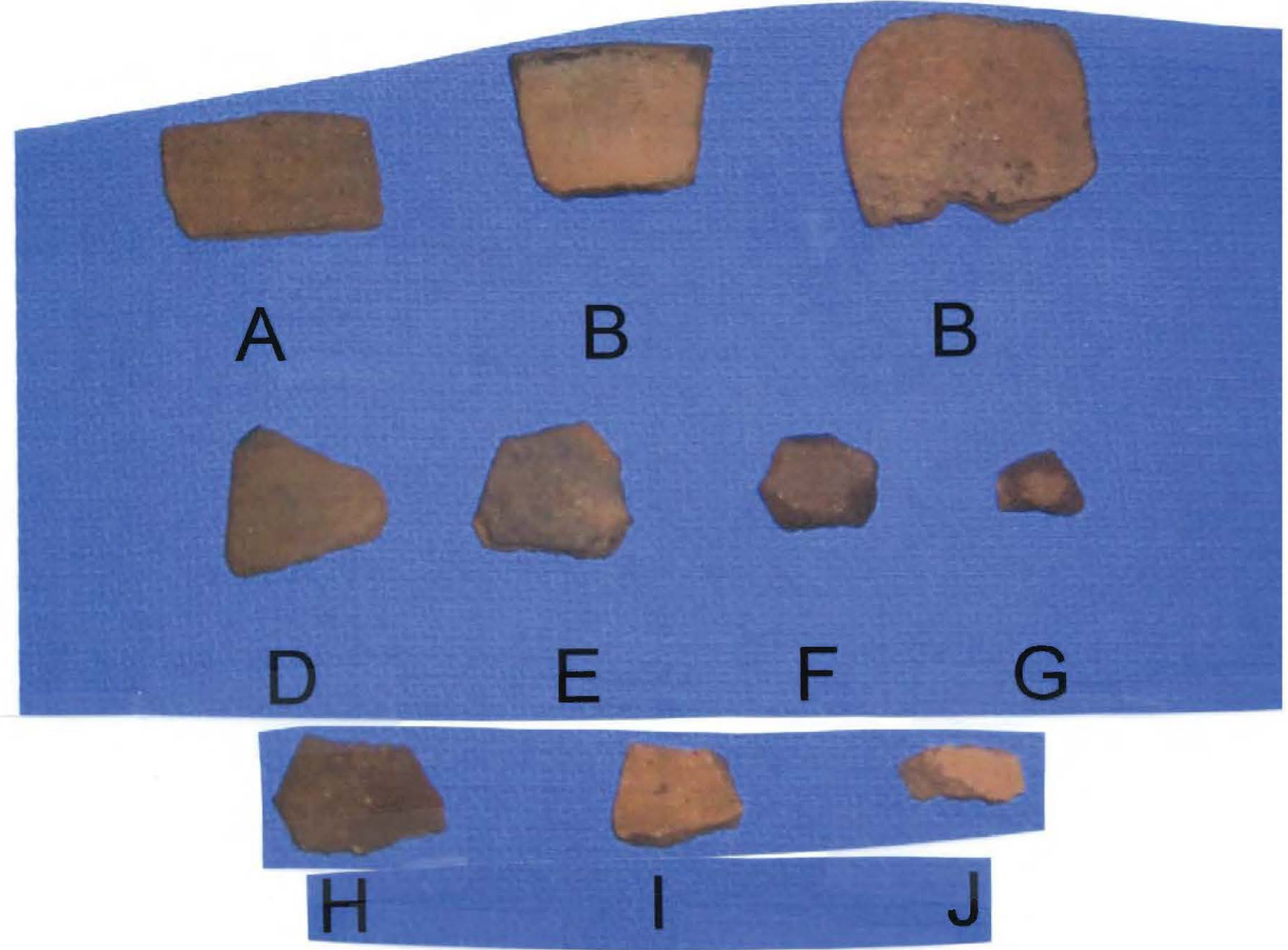

Figure 19. Pottery sherds from 41AN115.

Sandy paste pottery sherd, also a portion of the vessel rim (Figure 19b); slightly curved with a blackened interior; sandy brown in color; plain; grritty to the touch; $5 \mathrm{~mm}$ thick.

Sandy paste pottery sherd, slightly thicker than the others, possibly a base (Figure 19c); has a blackened interior, sandy brown in color, also gritty; $10 \mathrm{~mm}$ thick.

Sandy paste pottery sherd, small, plain (Figure 19d), sandy brown in color; $5 \mathrm{~mm}$ thick.

Small sandy paste pottery sherd (Figure 19e), plain with blackened interior; $5 \mathrm{~mm}$ thick.

Sandy paste pottery sherd, very small and plain (Figure 19f), brown in color; $5 \mathrm{~mm}$ thick.

Sandy Paste pottery sherd, very small and plain (Figure $19 \mathrm{~g}$ ), brown in color; $5 \mathrm{~mm}$ thick.

Shell and grog-tempered pottery sherd (Figure 19h), smooth and plain, blackened 
interior; $5 \mathrm{~mm}$ thick.

Grog-tempered pottery sherd, plain (Figure 19i); $6 \mathrm{~mm}$ thick..

Grog-tempered sherd, small and plain (Figure 19j); $6 \mathrm{~mm}$ thick.

\section{Discussion of Pottery Sherds}

We collected and identified eight sandy paste pottery sherds, and three grogtempered sherds from 41AN115. The sandy paste sherds include two rim sherds, with slightly curved profiles (see Figure 19a-b), one base sherd, and five plain body sherds. These were light sandy brown in color with black smudges on the inside. It has been suggested that there are two sandy paste pottery types (Goose Creek Plain, and Bear Creek Plain) found in this area, and the sherds from 41AN115 may belong to one or both of these defined types.

There was three other grog-tempered sherd, with one sherd having white specks in it that may be shell added for temper. All of these sherds are also plain.

The sherds were found in one area of 4IAN115, namely in the northwestern section. Because the sherds are from surface collections, we cannot determine with confidence what other artifacts they were associated with when they were left at the site. However, they were found in the same general area as the arrow points and the stone gouges. The presence of these pottery sherds suggests that the occupants had a less mobile hunting and gathering type of life, since they made and used pottery vessels, and this may indicate that there was a permanent settlement during part of the Woodland period at 4IAN1 15 .

\section{INVESTIGATION OF FEATURE 1 (UNIT I), 41 AN 115}

This feature, an ash deposit, was discovered because the asphalt company was taking top soil out of $41 \mathrm{AN} 115$. The ash deposit was exposed approximately $3.3 \mathrm{ft}$. (1.02 $\mathrm{m}$ ) deep at the bottom of a recently cut sand bank (Figure 20a). We decided to excavate Unit I here to better expose the feature and also to gather samples of charcoal for dating purposes.

The soil is a light sandy loam, which had four or five thin intermittent clay bands or lamellae running horizontally along the wall of the excavated area. We began our excavation in May 2002 with a $2 \times 2.5 \mathrm{ft}$. unit (Figure 20b), screening the sediments through 1/8-inch window screen, and collecting artifacts from every $0.5 \mathrm{ft}$. arbitrary level. As the excavations proceeded to $2 \mathrm{ft}$. $(0.61 \mathrm{~m})$, we found small pieces of rock, a few small flecks of charcoal, and a few very small flakes of chert. It was $0.5 \mathrm{ft}$. above the ash deposit that we found a flake of blue-colored chert, and then at the level of the ash (Figure 21) we found another flake of this blue Edwards Plateau chert. As we encountered the ash, we carefully removed the sand away from the ashy matrix, until we 


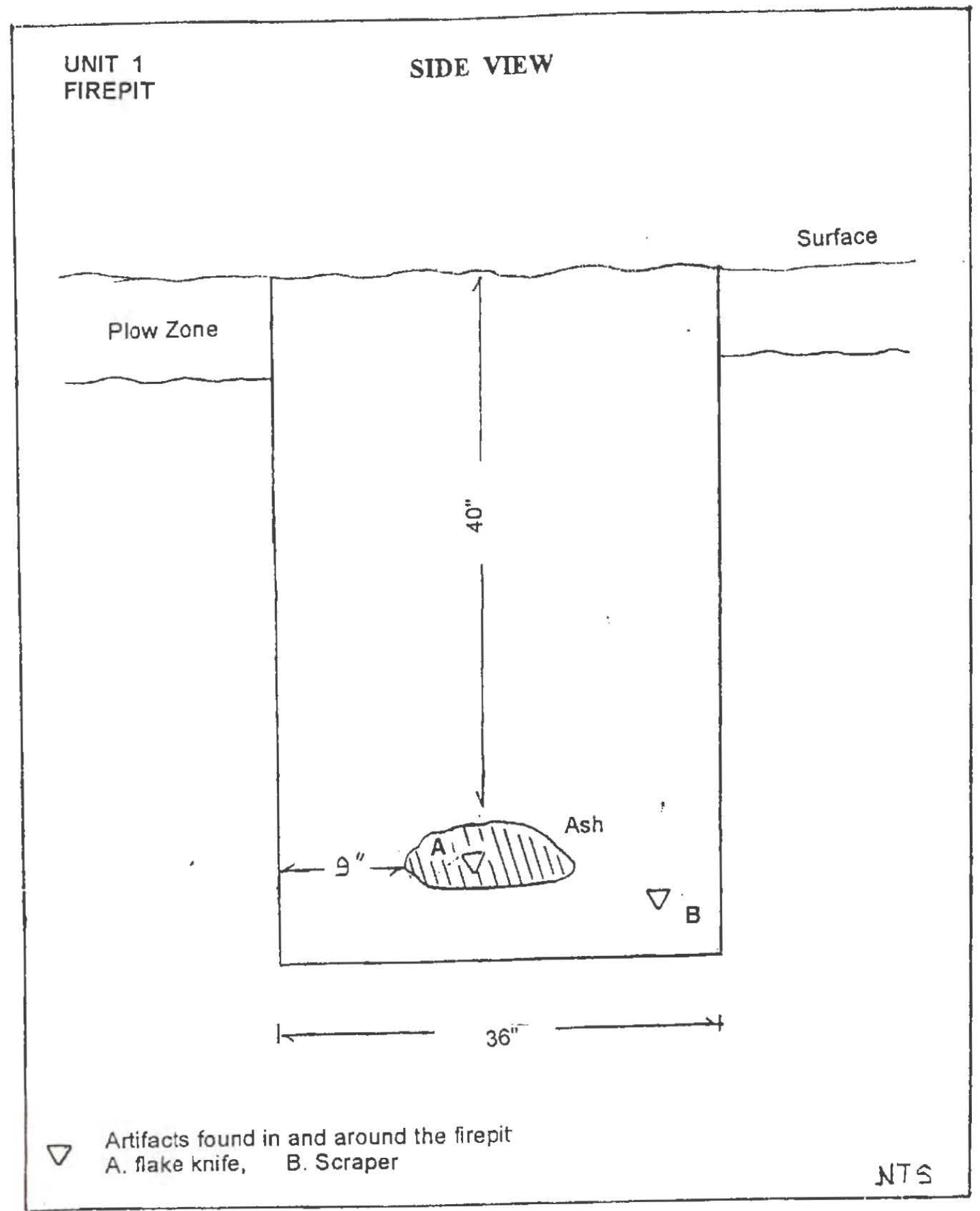

Figure 20a. Unit 1 profile and Feature 1. 
UNIT 1

TOP VIEW

FIRE PIT

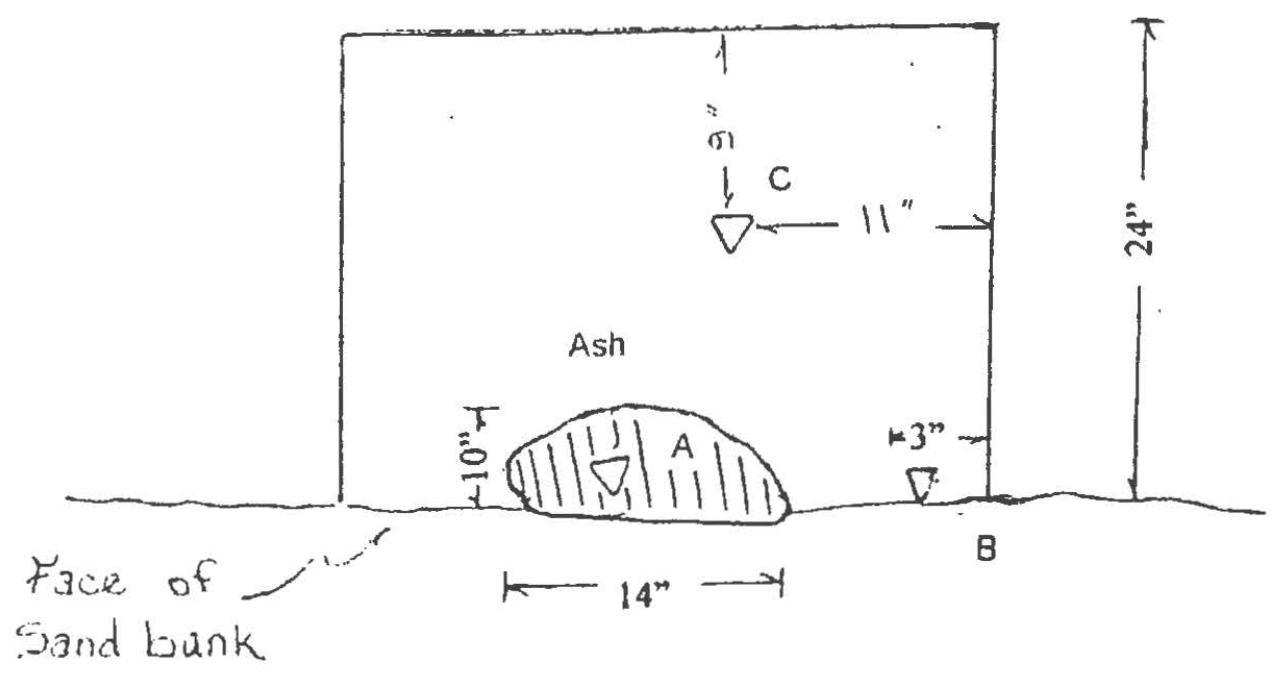

Artifacts found in and around the fire pit.
A. Flake knife
B. Scraper
C. Broken Biface

Figure 20b. Plan view of Feature 1 and associated artifacts.

were $0.5 \mathrm{ft}$. below the bottom of the ash deposit (Figure 22a-b). We found three chipped tools in the excavations: a broken projectile point behind the ash to the south; an end scraper on the west side of Unit I, and a flake knife inside the ash deposit itself. We carefully took the ash and charcoal apart, to retrieve samples of charcoal from the center for dating purposes, and put the rest of the ash in a bag for further investigation and study.

The charcoal $(30 \mathrm{~g})$ from the matrix of Feature 1 has been dated to cal $4100-4260$ B.P. and 4010-4400 B.P., one and two sigma, respectively. The two sigma calibrated results indicate that there is a 95 percent probability that the ash and charcoal feature 


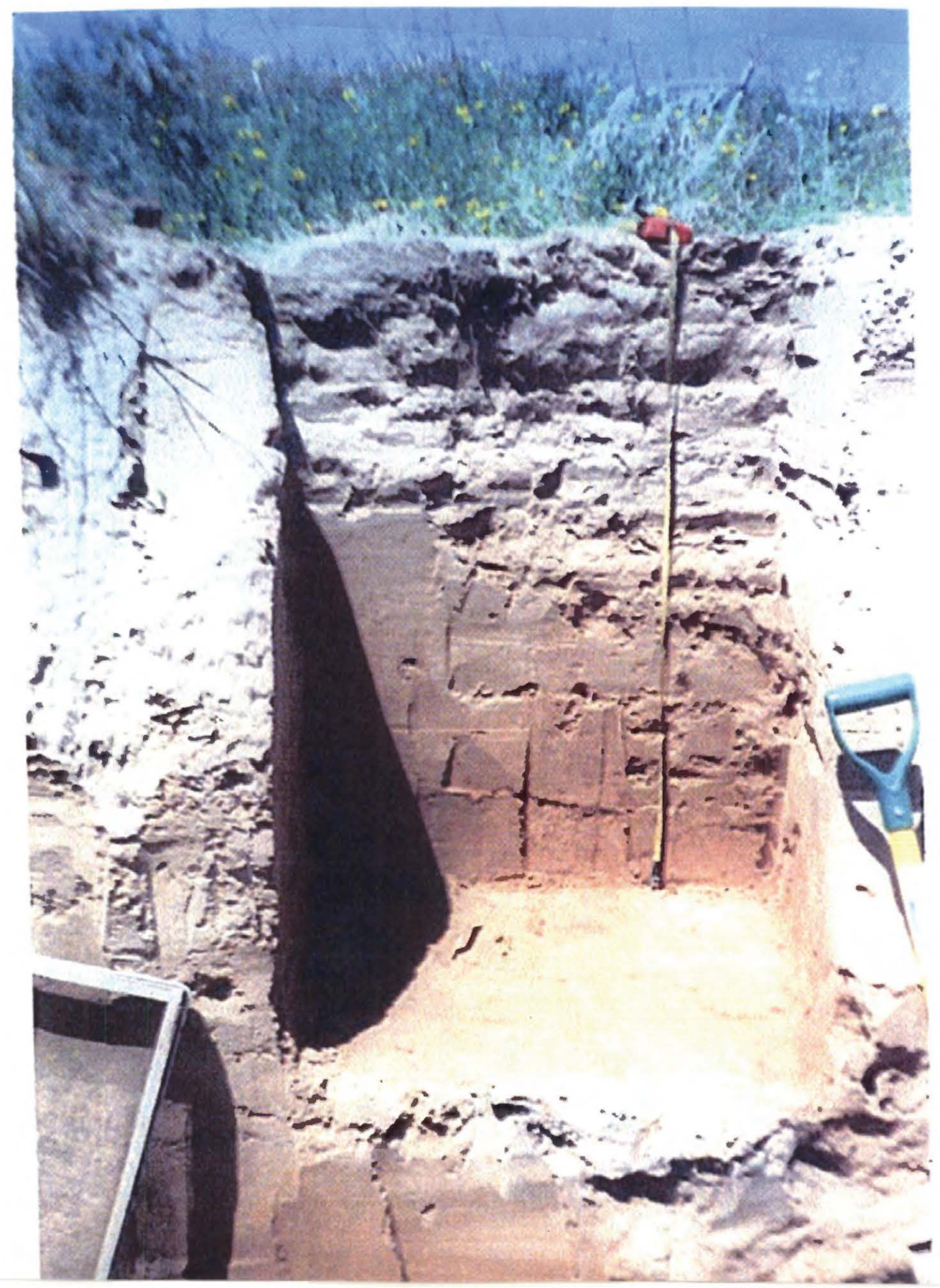

Figure 21. Looking at Unit 1 excavations, at a depth just above Feature 1. 


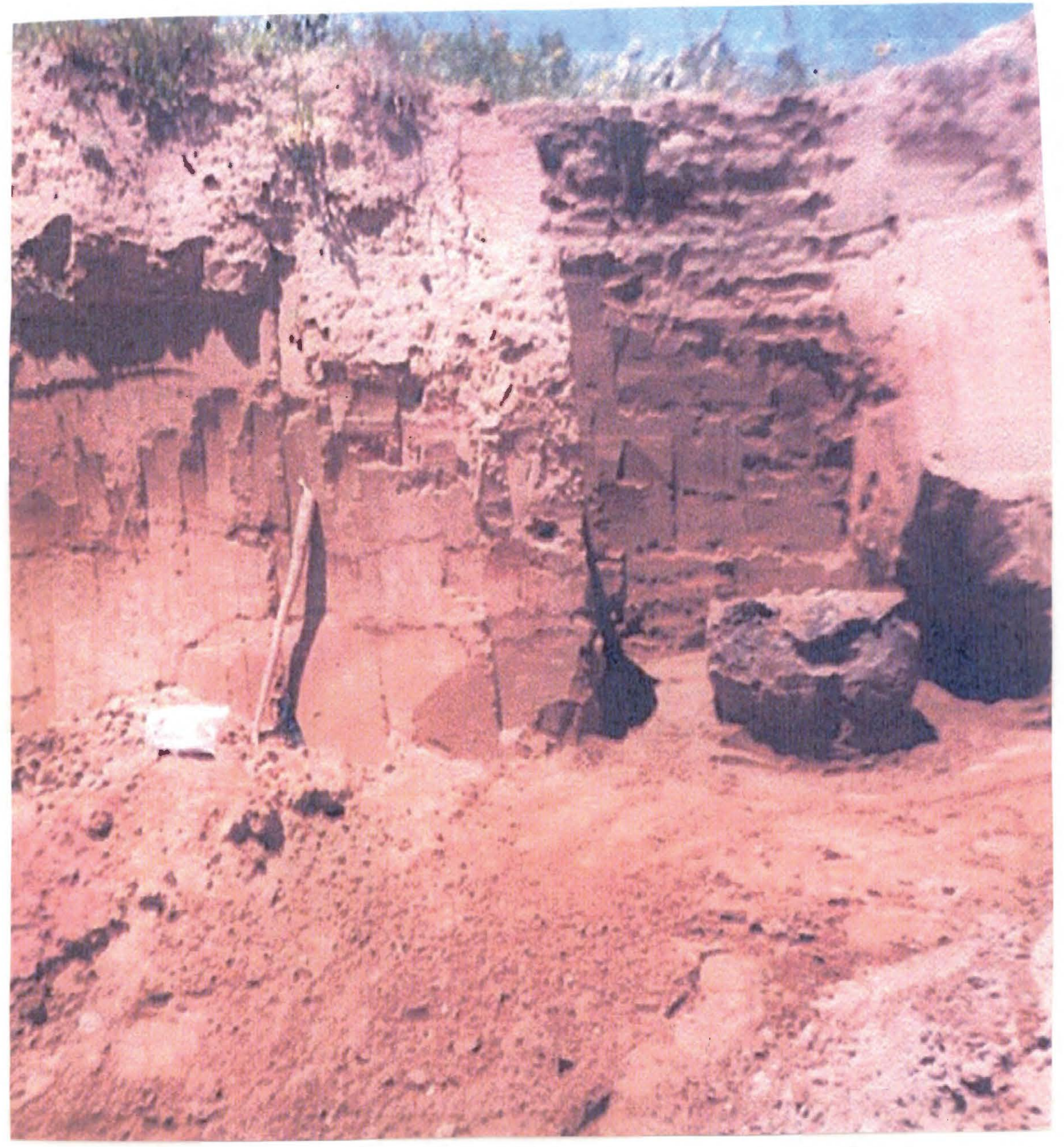

Figure 22a. Excavations in Unit 1, with the ash pit (Feature 1) at the unit base. 


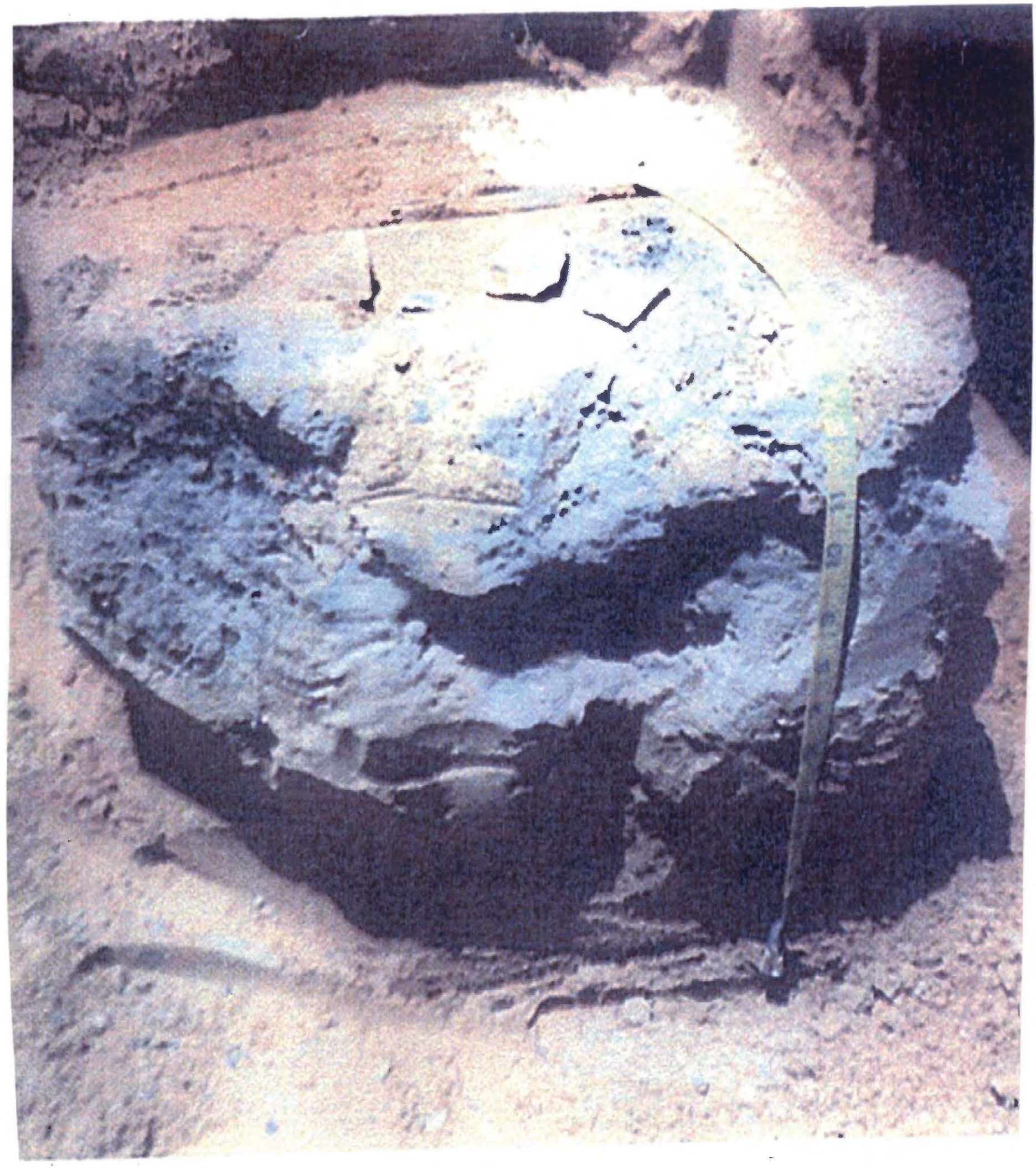

Figure 22b. Feature 1 ash pit before it was taken apart. 
dates between 2060-2450 B.C., with calibrated intercepts at 2220 B.C., 2260 B.C., and 2270 B.C. (Perttula 2002:44). Found in the charcoal matrix were three small pieces of ferruginous sandstone fire-cracked rock $(78.0 \mathrm{~g})$ and two pieces of quartzite lithic debris.

\section{DESCRIPTION OF FIRE PIT ARTIFACTS}

Scraper: a flat rectangular-shaped tool made from petrified wood (Figure 23a), with one end having a few flakes taken off one side to form a unifacial blade. The end has been step fractured, leaving the rest of the piece with no modification. This was found just below the level of the ash deposit, and apparently discarded after use; $52 \mathrm{~mm}$ long, 34 $\mathrm{mm}$ wide, and $13 \mathrm{~mm}$ thick.

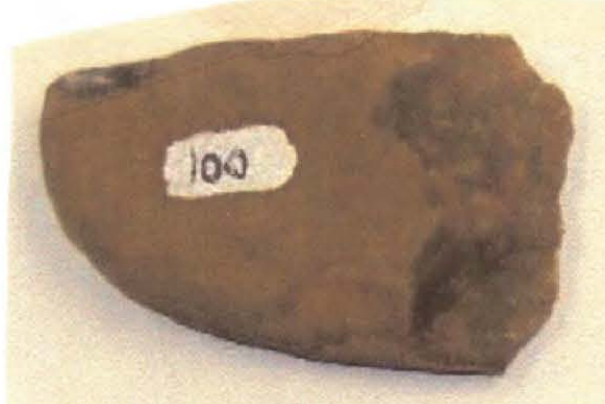

A
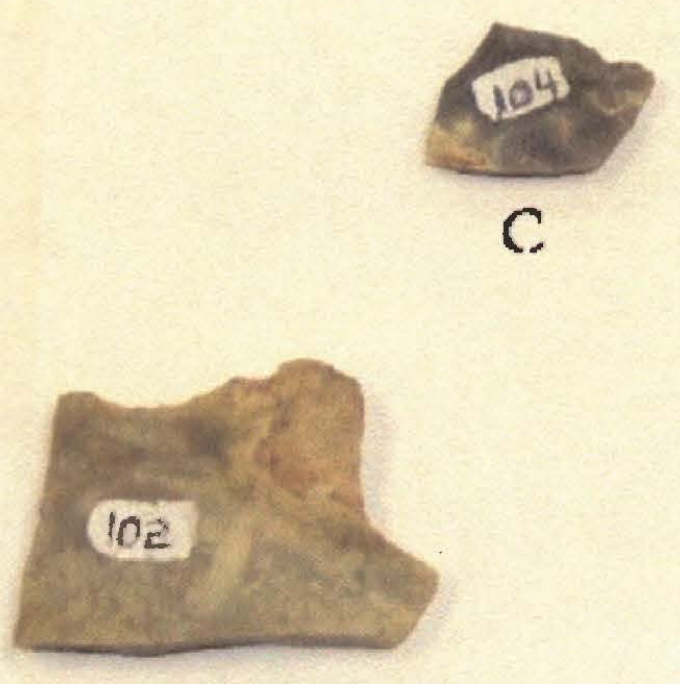

E

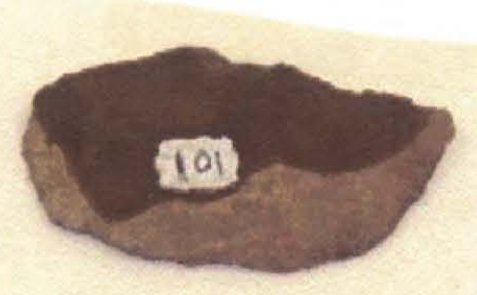

B

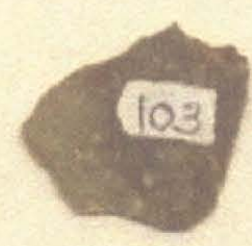

D)

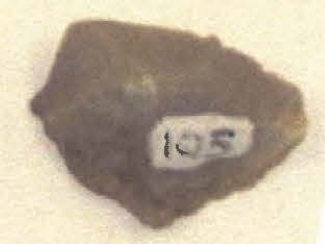

F

Figure 23. Feature 1 artifacts. 
Flake knife: a small knife, made from a flake, with one edge lightly serrated for cutting (Figure 23b). It is a small ovoid-shaped flake of a local reddish-brown chert. One side is flat from where it was detached from the parent core, and the other side has three or four flakes taken out for thinning. The cortex is still present on the end and along the top edge of the flake to the tip. This artifact was found inside the ash deposit when it was broken apart for the removal of charcoal for later dating; $45 \mathrm{~mm}$ long, $23 \mathrm{~mm}$ wide, and $5 \mathrm{~mm}$ thick.

Interior flake: a flake detached from a core by soft hammer kanpping to produce a small thin and rounded artifact with no cortex on either side (Figure 23c). This flake is on a non-local chert raw material: it is light blue in color, with tiny white specks in it, and is probably from the Edward Plateau area of Central Texas; $23 \mathrm{~mm}$ long, $20 \mathrm{~mm}$ wide, and $3 \mathrm{~mm}$ thick.

Interior flake: this interior flake has no cortex on either side (Figure 23d), and was produced by the soft hammer technique. It is on a light blue chert, with white specks in it; $22 \mathrm{~mm}$ long, $19 \mathrm{~mm}$ wide, and $3 \mathrm{~mm}$ thick.

Broken biface: the biface is also made from the light blue and white-speckled chert. It was chipped into what looks like the proximal end of a projectile point (Figure 23e). The base is small and rounded on the end, then expands to the shoulders, which flare straight out to the edge of the lateral blades. Both lateral blades have been thinned to where the material snapped laterally across the blade. The base still has some cortex on the bottom and on both sides of the stem. This artifact was found behind the fire pit, at the same depth; $40 \mathrm{~mm}$ long, $45 \mathrm{~mm}$ wide, and $7 \mathrm{~mm}$ thick.

Interior flake: This is a wedge-shape flake, thicker than the others, made from the same material (Figure 23f). One side has a ridge that runs the entire length of the piece, and the other side has a ridge running across the edges. This is a thick nodule with no cortex; 27 $\mathrm{mm}$ long, $16 \mathrm{~mm}$ wide, and $12 \mathrm{~mm}$ thick.

\section{Summary of the Feature 1 Excavations}

Because of the asphalt company taking sand out everyday, we had to excavate quickly with only one unit placed over the ash deposit. We then moved to stop the asphalt company from taking dirt out of this immediate area, until we can return and excavate a larger area around the fire pit. Of the artifacts found in and around Fea. 1-a broken dart point (see Figure 23e), a small flake knife, and an end scraper-only the broken dart point was chipped out of a non-local chert. The other two tools were manufactured from local lithic raw materials.

Our main findings from the Feature I excavationsare: (1) this was a small fire pit used for a very short time; (2) the occupants had killed and skinned one or more animals there. They were making and/or refurbishing tools for further use, and (3) from the one radiocarbon date we have from the feature, this was from a Late Archaic occupation at 41 AN115. 


\section{SUMMARY OF THE FINDINGS AT 41 AN115}

This preliminary report summarizes our investigation at 41 AN 115, the Bryant/Pearsoul site. This site is located on a terrace overlooking Town Creek; the creek drains into the Trinity River. We have surface collected for 14 months on this site, collecting and cataloging material and tools that document use of the site during Paleoindian, Archaic, and Woodland periods. This site has been used intermittenlly for approximately 7,000 years, if not longer, first on a temporary basis in the Paleoindian and Archaic periods, and then more permanently in the Woodland period. The only feature we found was a fire pit $3.5 \mathrm{ft}$. below the surface. Charcoal from the feature has yielded a 2 sigma calibrated age range of 4010 to 4400 years B.P.

The Paleoindian material consists of tools made from lithic raw materials not local to this area, including projectile points, flake knives, and scrapers. Occupations during later time periods had a much lower dependence on non-local lithic raw materials, and were instead characterized by the mix of local cherts and quartzite.

This site is located on a sandy terrace where the topsoil has been carried off, exposing tools and lithic debitage, especially after rains. Further back on the terrace where the sand is being excavated, sometimes up to a depth of eight feet, a large portion of the site's archaeological deposits have been carried off along with the artifacts that were left here. Along the northwestern part of the site, we were told that there were some small houses that had been occupied by black farmers who cultivated the land back in the $1930 \mathrm{~s}$ and 1940s. We found broken dishes and metal artifacts from this most recent occupation of the site.

The prehistoric archaeological record from 41 AN1 15 is a picture of cultural progression through time. This included the introduction of innovations in stone tools, as well as new ideas for a more sedentary lifestyle.

\section{ACKNOWLEDGEMENTS}

We would like to thank Joe Bryant and John Pearsoul for letting us collect, identify, and document artifacts from their property. Without their consent, it would not have been possible for us to examine and learn from the artifacts left behind by some of the first people to come into Anderson County. We would also like to thank Dr. Timothy Perttula, who obtained a radiocarbon date on the charcoal from the Fea. I pit we found, and gave us encouragement to document this site. In addition, we would like to thank Joe Warmke who took some of the pictures for us to use in the article. 


\section{REFERENCES CITED}

Perttula, T. K.

2002 An Early Radiocarbon Date from a Prehistoric Site in Anderson County, Texas. Journal of Northeast Texas Archaeology 16:43-44.

Turner, E. S. and T. R. Hester

1993 A Field Guide to Stone Artifacts of Texas Indians. $2^{\text {nd }}$ Edition. Gulf Publishing Company, Houston. 